\title{
By and for women: Involving women in the development of reproductive health care materials
}

\author{
Valerie J. Hull \\ Barbara L. Ibrahim \\ Population Council \\ Nadia Farah \\ Blanca Figueroa \\ Margaret Winn
}

Follow this and additional works at: https://knowledgecommons.popcouncil.org/departments_sbsr-pgy

Part of the Family, Life Course, and Society Commons, Gender and Sexuality Commons, International Public Health Commons, Maternal and Child Health Commons, Public Health Education and Promotion Commons, and the Women's Health Commons How does access to this work benefit you? Let us know!

\section{Recommended Citation}

Hull, Valerie J., Barbara L. Ibrahim, Nadia Farah, Blanca Figueroa, and Margaret Winn. 1992. "By and for women: Involving women in the development of reproductive health care materials," Quality/Calidad/ Qualité no. 4. New York: Population Council. 
frisig. 4

h. 3.

3. a. Intolving Wonven in the f

H- Development of Reproductive - Henlth Care Mnterials:

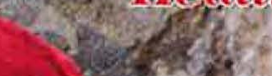


Quality/Calidad/Qualité, a publication of the Population Council, highlights examples of family planning and reproductive health programs that are providing unusually high quality care. This series is part of the Council's Robert H. Ebert Program on Critical Issues in Reproductive Health and Population which, through scientific and practical efforts, seeks to improve and expand the scope and quality of reproductive health care. The philosophical foundation of the program, and of this series, is that women and their partners have a fundamental right to respectful treatment, information, choice and follow-up from reproductive health care providers. The pamphlets reflect one of the four main thrusts of the program: enhancing the quality of family planning programs.

Projects are selected for documentation in the Quality/Calidad/Qualité series by an Advisory Committee made up of individuals who have a broad range of experience within the field of reproductive health and are committed to improving the quality of services. These projects are making important strides in one or more of the following ways: broadening the choice of contraceptive methods and technologies available; providing the information clients need to make informed choices and better manage their own health care; strengthening the quality of client/provider interaction and encouraging continued contact between providers and clients; making innovative efforts to increase the management capacity and broaden the skills of service providers at all levels; expanding the constellation of services and information provided beyond those conventionally defined as "family planning;" and reaching underserved and disadvantaged groups with reproductive health care services.

None of the projects documented in the series is being offered as a model for replication. Rather, each is presented as an unusually creative example of values, objectives and implementation. These are "learning experiences" that demonstrate the self-critical attitude required to anticipate clients' needs and find affordable means to meet them. This reflective posture is exemplified by a willingness to respond to changes in clients' needs as well as to the broader social and economic transformations affecting societies. Documenting the critical choices these programs have made should help to reinforce, in practical terms, the belief that an individual's satisfaction with reproductive health care services is strongly related to the achievement of broader health and population goals.

Publication of this edition of Quality/Calidad/Qualité is made possible by support provided by the Ford Foundation, the John D. and Catherine T. MacArthur Foundation and the United Nations Population Fund (UNFPA).
Statements made and views expressed in this publication are solely the responsibility of the authors and not of any organization providing support for Quality/ Calidad/Qualité. 


\title{
By and for Women: Involving Women in the Development of Reproductive Health Care Materials
}

\author{
Introduction and Afterword \\ by Valerie Hull \\ Case Studies by: \\ Barbara Ibrahim and Nadia Farah: Egypt \\ Blanca Figueroa: Peru \\ Margaret Winn: South Pacific
}

\section{Knowledge is Power}

\section{Introduction}

Information is the key to understanding and coping with change. It is the basis for enhanced self-awareness, empowering individuals to exert more control over their own lives. In the area of health, access to information not only can provide knowledge of what services are available, but also can expand the capacity for self-care and use of preventive measures, help people know when external assistance is required, and build the confidence people need to effectively seek out and use available health care. If the means of delivering information is appropiiate, it can be a powerful agent of positive change. If the message delivery is weak, the result is lost opportunities, wasted resources, even the spread of harmful misinformation.

\section{Women's Health: Who "Owns" the Information?}

Probably nowhere is the issue of access to information more critical than in the area of women's health-particularly women's reproductive health. In the latter half of this century, the trend in reproductive health has been toward the expropriation of care by professionals and away from the traditional providers of such services and practices: midwives and women themselves. Increasingly, knowledge has become concentrated among a specialized elite, with the result that health specialists, most of whom are male, are generally making many decisions that directly affect the health and well-being of women-whether setting priorities for development of new contraceptives, determining funding allocations among different types of health services or even establishing accepted childbirth and infant feeding practices-with women having little or no input.

Yet women are not without their own information systems; indeed, they often share health knowledge, beliefs and fears among themselves, both between generations and among peers. Such traditional information systems can be important components in the provision of quality health care, fully consistent with the objectives of primary and self-care approaches. Unfortunately, the tendency of specialists to restrict dissemination of information to lay audiences has limited the addition of accurate knowledge about new practices into these traditional networks. Ironically, rumors and misinformation are often more successful in filtering into these systems.

\section{Attempts to Deliver the Message}

Women have not responded passively to this situation. From the inception of the family planning movement, women leaders in many countries around the world, have taken strong, positive action to gain the essential right of women to control their fertility. In recent years, too, 
women's health groups have become increasingly vocal and active. A landmark contribution in this struggle is the Boston Women's Health Book Collective's Our Bodies, Ourselves. This book provides women with a comprehensive information resource for all their health-related concerns. Partially as a result of the success of Our Bodies, Ourselves, women's health collectives have become active in a number of developing countries; one of the case studies in this issue describes the work of such a group in Egypt.

Largely owing to the efforts of women working at the grassroots, provider and academic levels, there has been a growing recognition among family planning professionals that more than simply motivating potential clients is necessary: clients need to be provided with full and accurate information about methods and, in addition, services must be readily available in order to foster not only adoption but continued use of contraception. There has also been an increasing awareness that when accurate information is presented in a form that does not realisitically reflect available services or is unintelligible or unappealing to the intended audience, it is often no more helpful than no information at all.

\section{Information Materials by and for Women: Some Special Challenges}

So where do women come into this process? Does involvement of women in the design, testing, production and distribution of health information materials make a difference? How can women be involved and what happens when they are?

Development of health information by and for women faces not only common technical problems but also more basic challenges in working in the area of women's reproductive health care. Women, particularly poor women, are more likely to be marginalized both physically and within society. They are also more likely than men to be nonliterate or to have lost the ability to read through lack of practice, and they are more likely to have difficulty interpreting graphic illustrations or even photographs. In addition, they are often intimidated by or prevented from gaining modern information and are cut off from decision-making processes.

Another difficulty is that the field of reproductive health involves value-laden issues often regarded as being highly "sensitive"-occasionally by the women themselves, but more often by the male elite. This is just one reflection of the inherent communication difficulties that exist between men and women, especially in areas such as sexuality, childbirth and domestic violence. Hopefully, sometime in the future, men and women will all be able to discuss such issues openly, but that is not the case today. The process of developing health materials by and for women can provide a safe environment in which women are able to ask questions, discuss issues and share information that would never be possible in a coeducational environment. The process also helps to strengthen women's sense of self-esteem as they begin to see that they are not alone, that others share their problems and concerns and can even learn from their experiences.

\section{The Case Studies}

The studies in this issue of Quality/Calidad/Qualité describe this approach in three different settings in the developing world. In Cairo, a women's health collective produced a comprehensive reference book for women; in Peru, a woman's group, with the extensive involvement of their nonliterate audience, developed a series of illustrated teaching materials; and in the South Pacific, an all-woman production crew produced three motivation and teaching videos developed in response to the expressed needs of Pacific Island women. Despite contrasts in the characteristics of the intended audiences, the development process and the medium employed to deliver health messages, the projects are all characterized by the active involvement of women at all levels and in all stages of project development. The authors tell the story of their project, comment on how involving women made a difference and reflect on implications for future activities. In each case, women's involvement has resulted in a legacy of more than just a set of effective and well utilized information materials-it has mobilized the women involved and enabled them to help themselves. 


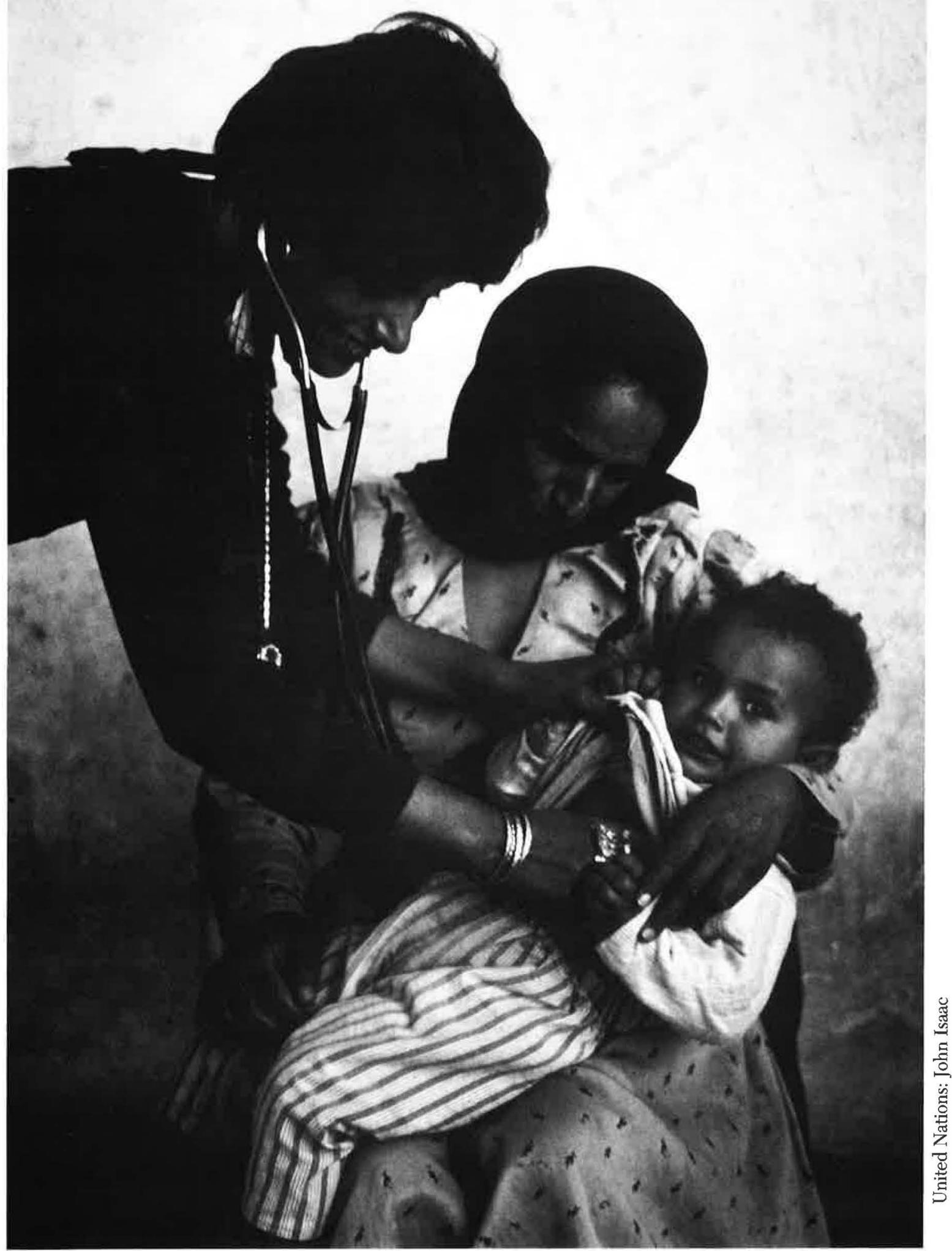




\section{Women's Lives and Health: The Cairo Women's Health Book Collective}

For the first time in my life, 1 read a book which talks directly to me, discussing my real problems and not the imaginary problems that men writers think we suffer from.

Pretest Participant

\section{The Setting}

In matters that concern health, Egyptians historically called upon an array of traditional practitioners from within their local communities, including faith healers, bonesetters and midwives. Increasingly, with the introduction of modern medicine, people have entrusted their health to doctors and to a technical system about which they remain largely ignorant. For women particularly, this can be a problem because high rates of illiteracy and codes of modesty restrict them from easy access to health information, and ignorance leads to a sense of helplessness rather than good health.

In addition, a current of cultural conservatism in the Arab world during the last decade has polarized viewpoints regarding women's economic and social rights, including rights to certain health services. Therefore, both cultural and medical considerations have complicated debates over issues such as the appropriateness of modern techniques to gain control over fertility. Those women who choose to plan the number and spacing of their children have found themselves in paradoxical situations. While, on the one hand, they may have battled to gain access to modern contraceptive services, such as oral contraceptives, and have been increasingly vocal about harmful traditional practices, such as female circumcision; at the same time, they may have serious reservations about the unquestioning adoption of some modern medicines and medical practices. As an example, until women launched a successful public campaign for its regulation, the controversial drug Depo-provera was sold over the counter in Egyptian pharmacies. (In many Third World countries, as in Egypt, contraceptives and drugs such an antibiotics are routinely sold in pharmacies without a prescription.)

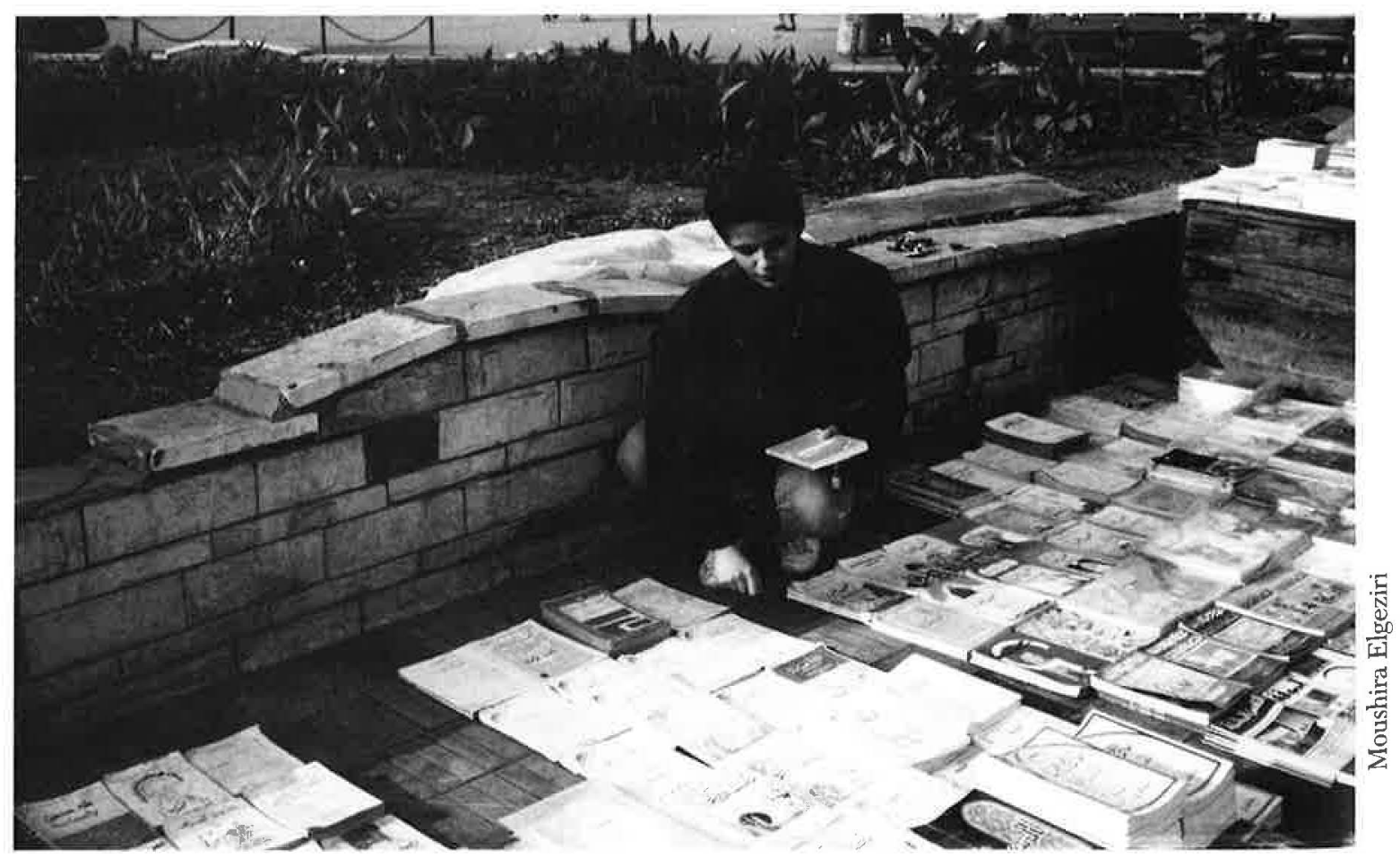




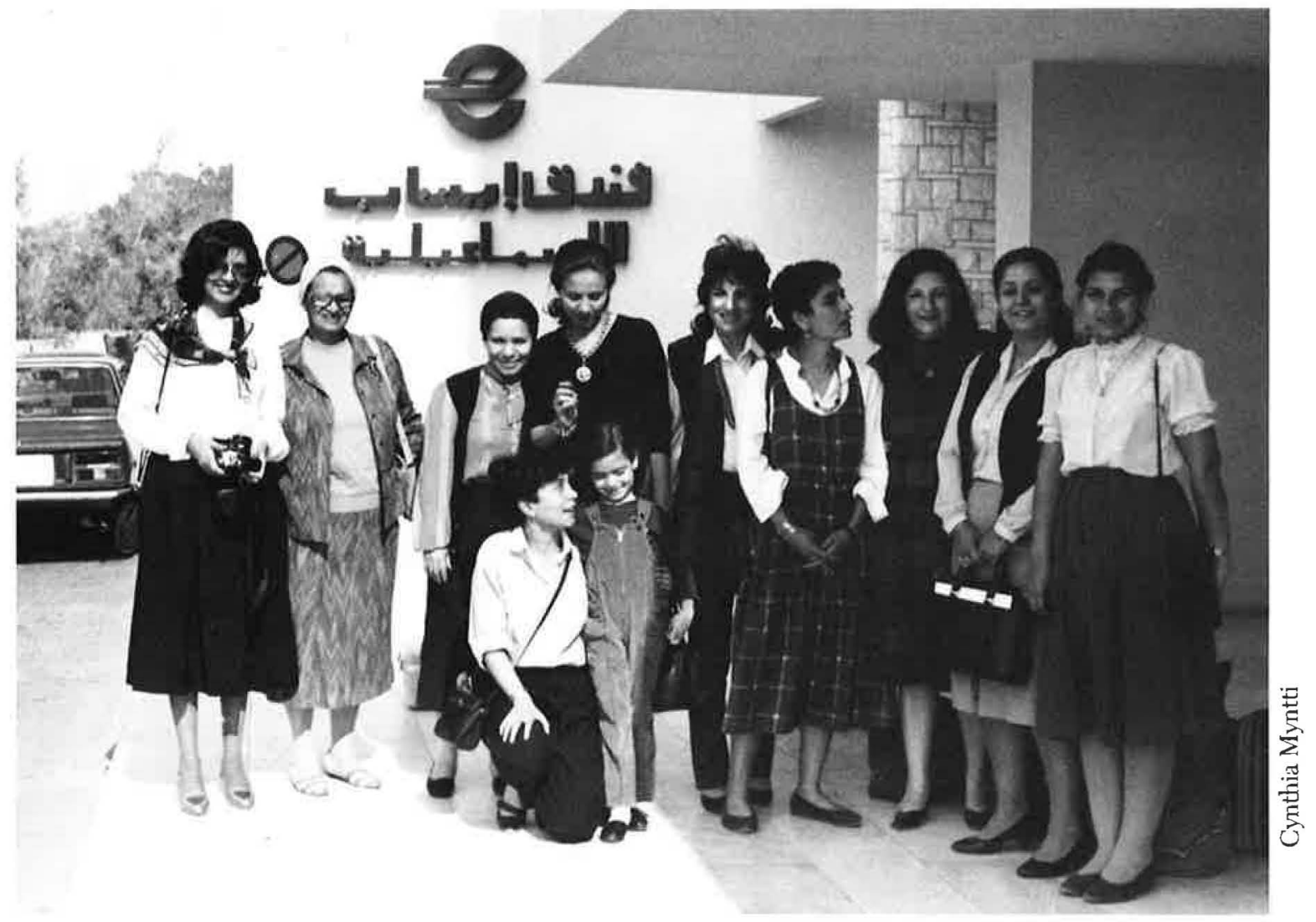

\section{The Collective}

Concern over problems such as these led a small group of activist women in Cairo to begin informal discussions on issues of women's reproductive health in Egypt. Some of the women were familiar with the Boston Women's Health Book Collective and its path-breaking health guide for women, Our Bodies, Ourselves. As they explored various options for informing Egyptian women about health issues, it became clear that practical health information in the nature of a guide or reference book was virtually nonexistent in the Arabic language. The books and magazines that were available commercially were either overly technical or so simple as to be incomplete or misleading; moreover, most existing publications contained an implicit message that medical knowledge is a privilege best restricted to doctors.

Based on these observations, the group decided to take action and began planning a women's health information project. They were guided by three basic principles: 1) women have a right to information about issues touch- ing deeply on their lives and health; 2) health information should be presented simply, clearly and in a language that women can understand; and 3) above all, health information should be practically oriented, so that women are encouraged to become actively involved in keeping themselves healthy and in making informed choices.

Before deciding precisely how to proceed, the group advertised for and selected a coordinator who would devote full time to overseeing the project. An initial task of the coordinator was to expand the size and breadth of the original group, which had been comprised mainly of elite social scientists. A group of 25 women from a variety of social classes, from all age groups and from fields such as medicine, teaching, media and development were approached to attend a founding meeting of the Cairo Women's Health Book Collective in the Suez Canal city of Ismailia in April 1985. Twenty-two of the women continued with the project until its completion. 


\section{Developing a Health Book by and for Women}

Now I can give my daughter a book that answers all her questions scientifically, objectively and without making her feel ashamed of her own body or self.

Mother of 13-year old girl

The Collective's first meeting was structured as a three-day retreat in which the women could get to know each other and begin to define the fundamental nature of the Collective, as well as set priorities for action. They agreed on the following basic points to guide their future work:

1) They would write a health guide for women that would reflect the culture and contemporary circumstances in Egypt. It would be an original work, rather than a translation or adaptation of an existing volume. However, they would consult examples from other countries in order to learn from their approaches.

2) The book would be written from the perspective of women, in a friendly, respectful and accessible style. While its intended audience would have a high-school-level reading ability, the book would invariably reach beyond that audience since literate women in Egypt often live among and share what they learn with other nonliterate female family members and neighbors.

3) The health book would be objectively written, not imposing any set of views on readers, but instead helping women reach their own conclusions.

4) All decisions about format, content, publication and distribution would be made through democratic processes. The entire group would debate any areas of disagreement so that the manuscript wouid reflect the collective views of all members, rather than the personal views of individual writers.

The planning and production of such a comprehensive volume required extensive discussion and collaboration, not only among the collective members but also between the Collective and outside experts and, most important, with representatives of the intended audience. The goal of the Collective was not only to produce a health book by women, but for the women who would buy and use it.

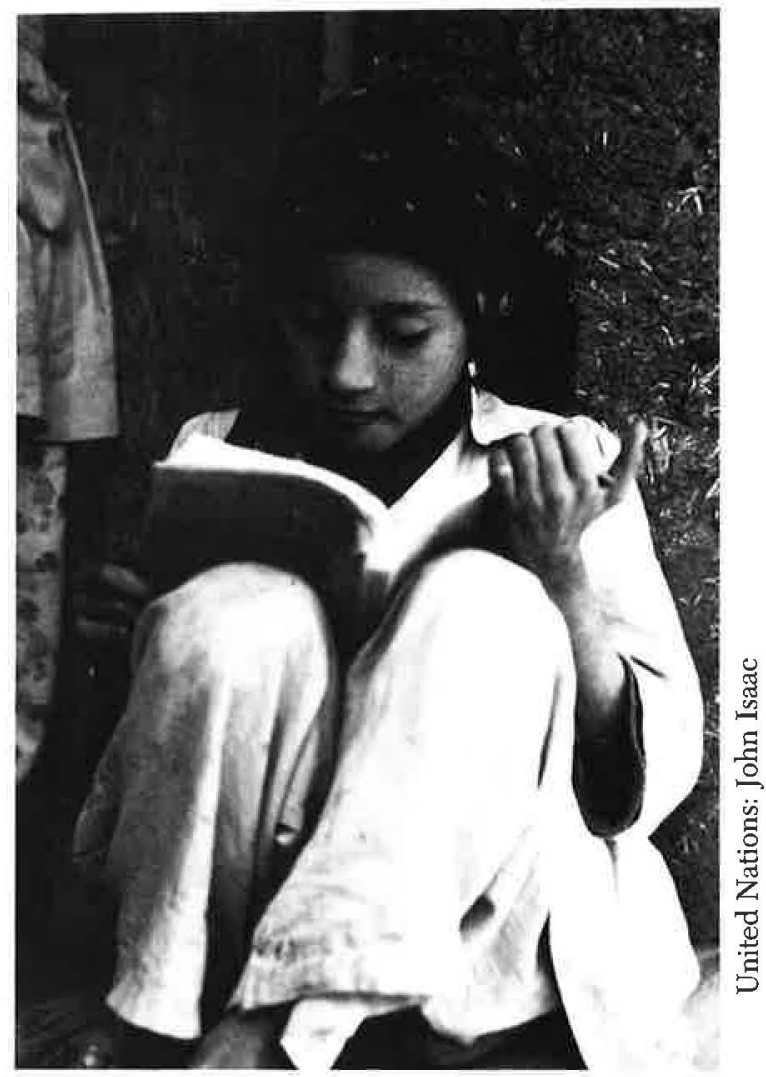

Each chapter was written by two or three women having an interest in the subject. The original idea was to have a technical/medical specialist, a social scientist and a good writer work on each chapter, but this did not prove to be practical in all cases. The coordinator applied for and received funding from the Ford Foundation and Oxfam, U.K. in order to defray publication costs, the coordinator's salary and small honoraria for members of the writing teams.

Over a period of two years, the Collective met about twice a month to review draft chapters and assure the collaborative character of the manuscript. Points of disagreement were resolved by negotiation and compromise. On some points the medical professionals felt that too much information could be confusing or dangerous for lay readers. For example, in the chapter dealing with surgical procedures such as hysterectomy, the doctors were uncomfortable with a section encouraging women to question recommended surgery and get a second opinion. The Collective, however, decided in favor of a woman's right to have complete information, to question medical procedures and seek corroborating opinions. 


\section{Content}

The book begins with a series of chapters that take a life cycle approach to women's experiences. To set the cultural context, an introductory chapter discusses Egyptian women's perceptions of themselves, their status and health. Subsequent chapters deal with the stages of childhood, adolescence, marriage, childbearing and rearing, menopause and old age. Then the book shifts to address a series of important health issues across ages, including those which are socially determined such as occupational health and safety. The chapters are described in the box below.

Debates over what topics to include in the book and how they should be handled were numerous-not surprising given the diversity among Collective members. The subject of violence against women, for example, aroused high emotions. Some Collective members held to the belief that rape is essentially a sexual act that women invite by their inappropriate dress or behavior. Others objected to the chapter on the grounds that the issues of rape and wife abuse would cast all males in a negative light and antagonize readers. Many hours were spent in discussion and a process of collective selfeducation before these issues were resolved.

In the end, the Collective agreed to devote a full chapter to violence against women. Because of the sensitive nature of the material, extra care was taken to document violence (rape, wife beating, child abuse) from Egyptian data and research findings. To provide balance, the chapter addressed not only male to female violence but female to female violence as well, including physical abuse directed at weaker family members and household help. Both male and female violence are described as the result of repressive social conditions rather than innate qualities of either sex.

A major challenge was to find approaches that would not offend the religious feelings of Muslims or Christians, without sacrificing objectivity or the pro-women nature of the book. The Collective acknowledged the importance of religion in Egyptian society and put forward positive interpretations of religious tenets, such as Quranic quotes emphasizing the importance of protecting women's health, highlighting the rights of female children and supporting equal relations in marriage. Despite a wide range of religious perspectives among Collective members, they generally agreed on the importance of reinforcing those religious values in their society that are supportive of women.

Controversial issues were discussed at each stage of preparation, from original outline to subsequent drafts. In all, each chapter was revised at least four times to take into account suggestions by the Collective and to respond to criticism of content or style.

\section{Review and Revision}

Now I know a lot about my own body and self. I am recommending the book to all my friends in school and we plan to read it together with other friends and...to the women in our families who cannot read it on their own.

\section{Young girl of 14}

At midpoint, the Collective held a two-day seminar to make an overall review of drafts, to select graphics and to discuss matters relating to consistency of Arabic tone and usage. A group of outside reviewers was invited to participate in this process, including a respected male

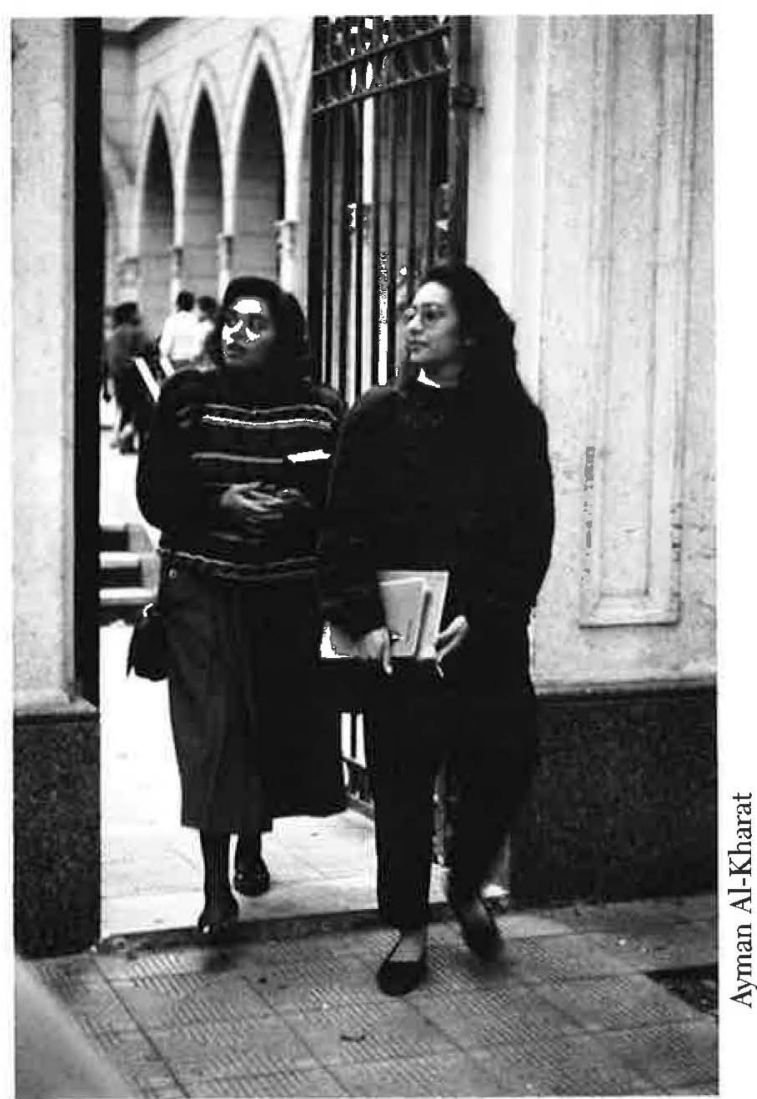




\section{Hayat al Mara... \\ Women's Lives and Health in Egypt}

\section{Contents}

\section{Egyptian Women's Perceptions of Their Lives and Health}

Describes women's perceptions of biological gender attributes, friendship and love, beauty, love and sexual relations and multiple roles of women in society. Identifies some cultural stereotypes such as the perception that femininity involves physical beauty and weakness.

\section{Childhood: An Important Phase of Women's Lives}

Discusses infant health care and traditional forms of discrimination against female children (Egypt is one of the few countries in which female infant mortality rates are higher than male rates) and social and psychological damage associated with female circumcision.

\section{Adolescence}

Reviews the physical changes in both boys and girls and emotional changes during adolescence. Provides detailed information on menstruation and reproductive biology as well as helping women achieve balance between desire for independence and the need for relationships.

\section{Marriage and Sexual Relations}

Talks about sexual relations in the context of marriage (responding to prevailing cultural values). Emphasizes the importance of communication and need to overcome stereotypes such as a male's right to initiate or withhold sex. Gives suggestions for improving intimate communication and mutually agreeable sexual experiences.

\section{Fertility and Infertility}

Refutes the notion that women are solely responsible for infertility (which results in loss of status and frequently divorce or abandonment). Discusses causes of infertility and methods that can help couples with this problem.

\section{Pregnancy, Childbirth and Breastfeeding}

Stresses positive traditions of family involvement during pregnancy and birth, as well as importance of medical supervision of pregnancy from an early stage; describes warning signs that demand prompt medical attention. Reinforces tradition of breastfeeding, showing health and emotional advantages.

\section{Abortion}

Addresses this sensitive topic by providing information on reliable contraception and various options for unwanted pregnancy. (Although not uncommon, induced abortion is illegal in Egypt, except when the mother's life is threatened.)

\section{Regulating Fertility: Women's Rights, When and How}

Reviews all major methods of fertility regulation, giving balanced views, pro and con, of each method and leaving the choice to each individual woman.

\section{Life After Menopause}

Focuses on the positive aspects of life for older women and how to cope with physical, psychological and social changes accompanying menopause.

\section{Nutrition}

Presents general nutritional advice, stressing high prevalence of anemia among women and girls, its avoidance and treatment. 


\section{Infections, Malignancies, Common Health Disorders}

Recommends regular checkups (not a common practice) and overcoming reticence to seek care for infections, observed lumps or other problems as soon as they appear.

\section{Traditional Health Care}

Offers a balanced view of traditional practices by reviewing scientific evidence on efficacy and noting beneficial as well as harmful practices.

\section{Women and Work}

Reviews in a balanced manner risks associated with work, including health hazards in performing household work, such as unsafe cookstoves; occupational hazards for women in agriculture caused by use of fertilizers and pesticides; hazards in offices and factories due to unsafe materials and machinery; and, while presenting employment for women positively, discusses the work-related stress many women experience attempting to fulfill multiple responsibilities.

\section{Violence Against Women}

Covers rape, physical and psychological abuse by employers or family members, incest and abusive treatment of servants and child laborers. Emphasizes how women can protect themselves from violence.

\section{Social and Psychological Pressures}

Addresses gender stereotypes and suggests how women can learn to reduce stress by seeking more egalitarian relationships in the family; sharing problems with husbands, family members or trusted friends; or by seeking professional help.

16. Available Health Care Services and Medical Care in Egypt

Comprehensive directory of services with special emphasis on women's health needs.

\section{因总}
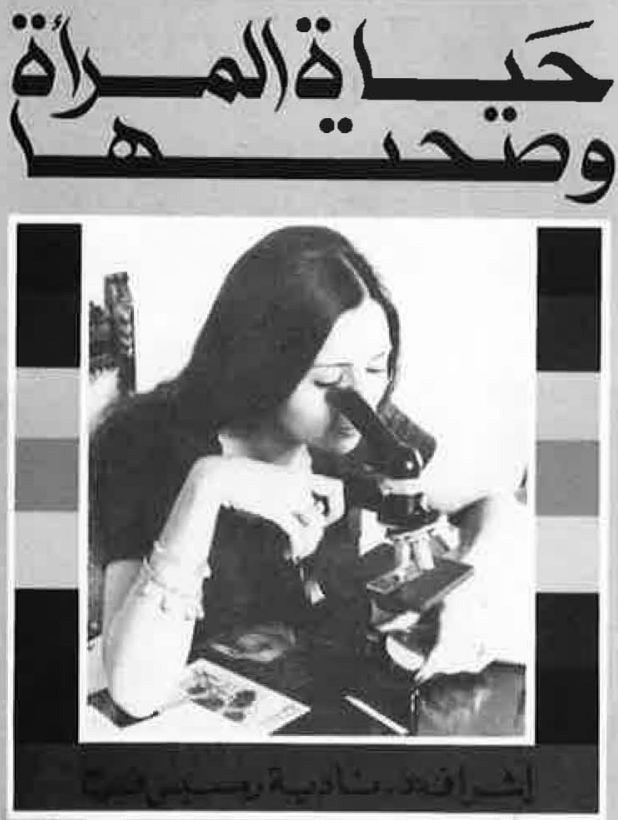

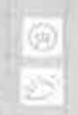

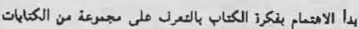

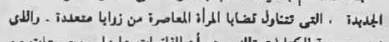

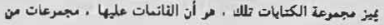

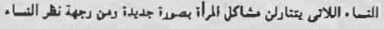

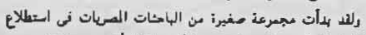

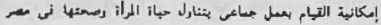

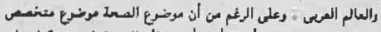

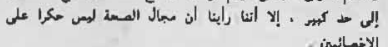

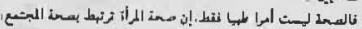

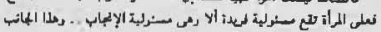

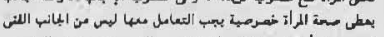

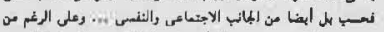

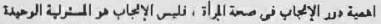

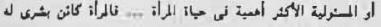

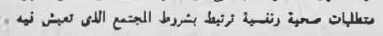

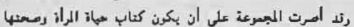

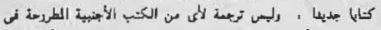

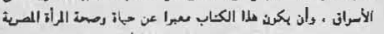

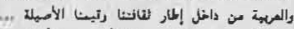

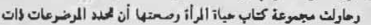

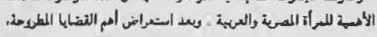

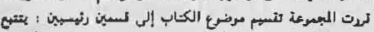

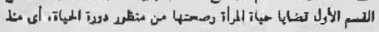

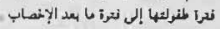

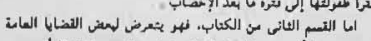

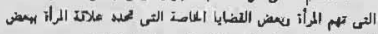

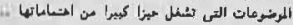

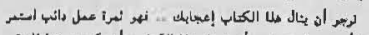

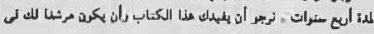

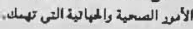


gynecologist, a professional editor and an illustrator. One of the reviewers was also knowledgeable on matters of Islamic law and traditions. While some members were initially against male participation at this stage, the Collective agreed it would be useful to have the benefit of male insights and perspectives.

Reviewers played an important role at the seminar; making a number of suggestions that improved the accuracy and clarity of the manuscript. By displaying some nonsexist attitudesas well as a number of stereotyped responsesthe male participants gave useful feedback concerning how the general public was likely to receive the book.

Following the seminar, two chapters were selected as a sample for pretesting on an audience of Egyptian women. The pretest was carried out to gauge public reaction to important aspects of the book: language, style, format, illustrations and, especially, the content itself. Would women find the presentation of sensitive material on sexuality acceptable? Would they easily understand the style of written Arabic? Would they find the book's tone friendly and accessible? One hundred women from different backgrounds and ages participated in the first pretest.

The results were encouraging. They indicated that the Collective had come up with a book that filled a real need. Several women said that this was the first time they had read about vital issues in their lives from a woman's perspective. The pretest demonstrated that the material was accessible even to women with less education than originally envisioned. It also reinforced the validity of the book's style, which was a mixture of standard Arabic and colloquial dialect as used in daily newspapers.

The illustrations selected by the Collective ranged from medical diagrams to photos, line drawings to cartoons. Readers in the pretest favored the scientific illustrations and approved of the photos, but responded poorly to cartoons and humorous drawings. This finding surprised some members of the Collective who thought cartoons were a striking way to present information. On reflection, the Collective realized that cartoons are typically used in Egyptian public life to ridicule an idea or person. Unintentionally, the use of cartoons detracted from the seriousness of health topics and cast women in a negative light. As a result of this review, cartoons were excluded from the book.

Following the pretest, the complete text was revised and subjected to another review by five women readers who had provided exceptionally helpful comments during the first pretest. Further editing ensured consistency of syntax and a unified "voice" throughout the manuscript, important in a book written by many different authors. A final screening was done to reduce any language that sounded like "preaching" to women.

\section{Publication and Dissemination}

The final product, published in early 1991 by a woman-owned press, features clear type and illustrations, has a durable binding and is a size somewhere between a book and a magazine, to ensure easy handling. In lieu of royalties, the Collective negotiated a discount on all orders placed through its members, thus enabling distribution to women's associations and other social organizations at minimal cost. Even so, the publisher dropped most of the illustrations planned for the book in an effort to keep the retail price low. This decision disappointed the Collective members, who will insist on replacing the illustrations when the book is reprinted.

The Collective hopes that the book will be circulated widely in Egypt and other Arab countries where women's problems are similar. Sales in high-income Arab countries may help subsidize editions for lower-income countries such as Sudan, Yemen, Tunis and Morocco.

\section{The Future}

For the first time in my life, I am feeling the depth of my deprivation as an illiterate woman. I am going to go to literacy classes so I can read the book on my own.

25-year old nonliterate woman

The Collective met shortly before publication of the book to plan for a public conference to include media representatives, leaders of nongovernmental organizations, health organizations and others interested in women's health. The meeting was held in March 1991 to 


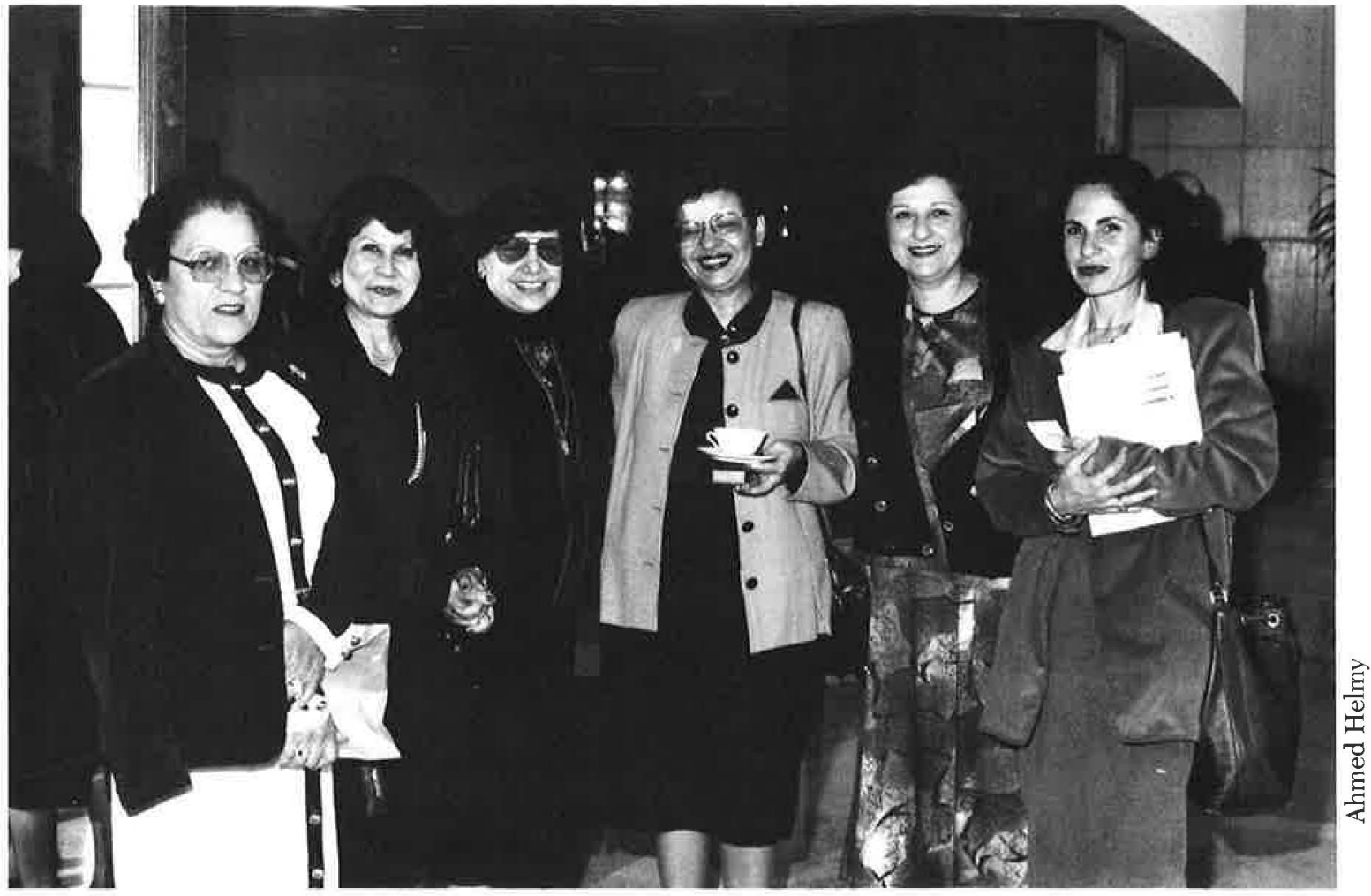

introduce the book and its authors, with participants encouraged to disseminate information on the book as widely as possible and to use it in their ongoing activities. In advance of the meeting, 200 copies were distributed free of charge to important individuals and associations working in the women's health field. Subsequently, the Cairo daily press reviewed the book several times. Sales of the book have been higher than anticipated, leading to a second printing scheduled for early 1992.

With the major effort of producing the health guide behind them, Collective members have turned their attention to the future. Some of the suggested activities include using the book in health training courses; revising and separating chapters and issuing them as pamphlets; and distributing the book outside commercial channels such as to clinics, women's organizations or schools. Interest also has been expressed in training social workers in rural areas, where women's illiteracy is high, to use the book as a tool in literacy courses. Collective members hope to explore other media channels, such as video or television, newspapers and women's magazines, to expand the educational resources available on women's health issues.

Although the entire group no longer meets regularly, many enduring ties have been formed, both socially and professionally. All of the members believe that the experience of working on the women's health guide has enriched them and given them valuable insights into the nature of collaboration. These experiences will be important as Egyptian women take their place in the current movement for greater freedom of expression and participation in national life. 


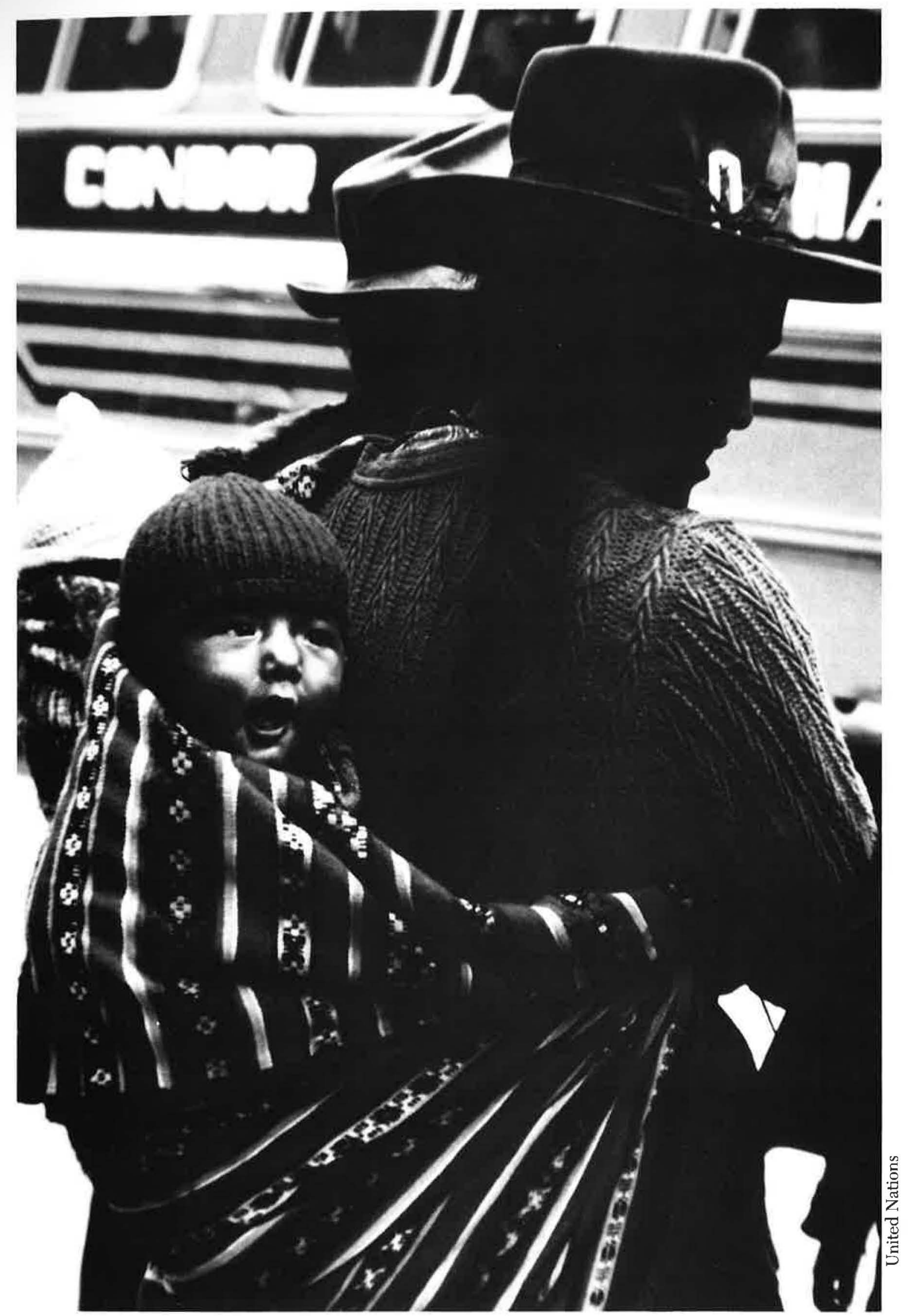




\section{Adding Color to Life: Illustrated Health Materials for Women in Peru}

\section{Background}

Until about 12 years ago, leaders of grassroots women's organizations in Peru were not interested in promoting family planning. They associated messages about women controlling their fertility with the "individualistic" rhetoric of feminists in developed countries. But in Peru, as in many other parts of the Third World, leaders of the women's movement have modified their view in recent years, realizing that the desire to control the number and spacing of children is almost universal among all women regardless of economic or social position. With this acknowledgment has come a growing participation by feminists in intellectual, political and practical efforts to increase women's access to information and services related to sexuality and family planning.

\section{Peru-Mujer}

It was within this environment that PeruMujer, a nongovernmental organization, was created in 1979 by two women researchers interested in helping low-income women improve the quality of their lives. Using a participatory method of group dynamics as their basis, Peru-Mujer began conducting workshops on subjects such as lifetime projects, sexuality and family planning, legal rights and small enterprises for groups of women throughout Peru. Special emphasis was placed on having the women define and seek solutions to social problems themselves. The strength of the approach was the intense emotional response and the sense of group identification experienced by the women. The weakness, PeruMujer staff were soon to realize, was that when these inspired women returned to their daily routine, they had few tools at their disposal either to help them maintain their enthusiasm or to begin to make changes in their own lives.

\section{The Project}

At just the time when the staff of PeruMujer were wrestling with the problem of how to enhance the participatory process, they were approached by PATH, the Program for Appropriate Technology in Health, (then known as PIACT, the Program for the Introduction and Adaptation of Contraceptive Technology), to develop a pamphlet on family planning and another on a health issue of their choice for use by illiterate women in Peru. Beginning its work in Mexico in the late 1970s, PATH/PIACT pioneered development of a methodology to produce simple print materials easily understandable by illiterate and low-literate audiences. Their client-centered approach involves the training of local personnel in the materials development process and has been used throughout Latin America, Africa and Asia.

Peru-Mujer staff reviewed materials developed by PATH/PIACT projects in other countries and were impressed by the attitude of respect exhibited toward cultural values. They saw here an opportunity not only to involve women in dialogue but to include them in the materials development process as well.

While visual materials for primary health did exist in Peru, they had not been tested to determine how well they were understood or accepted, especially by illiterates. In addition, most of these materials reflected urban conditions found in the country's coastal region. Since Peru is a diverse country, one of the first things Peru-Mujer decided was that a single, national booklet on either family planning or immunization (the health theme they chose to promote) would not work. Rather they decided to develop a separate version for each of the country's three major regions: coastal, jungle, and mountain.

\section{Learning the Methodology}

Illiterate people have their own view of the world, a different interpretation based on their own experiences and a legacy of oral tradition. A person with poor or nonexistent reading skills does not view illustrations in the same way a literate person does. The project began with a workshop conducted by PATH/PIACT for Peru- 
Mujer staff in the use of their methodology. In this approach, the emphasis is always on the audience (in this case local women). They are the "experts" both in terms of what they need to know and how the information is presented. Thus a women-centered approach was created that made use of the underlying knowledge and experience women already possess, confirming knowledge and practices that are positive and building a basis of trust on which to begin changing those that are negative.

One important way of doing this was to be certain that the women could recognize themselves in the illustrations. Drawings of people who seem familiar create a sense of emotional identification and provide an opening through which new concepts and information can be introduced and retained. In designing materials, it was also necessary to keep in mind that a woman's ability to access and use health technologies depends to a significant extent on her relationships with the people around her, including power relations within the family and community.

Armed with the new skills they had learned, the Peru-Mujer staff embarked on a three-phase project: 1) talking to the women to find out their knowledge, attitudes and values concerning family planning and immunization; 2) based on the information gathered, developing a set of materials that present information on these themes in a way that is understandable and culturally acceptable; (3) testing the materials with the audience to be sure the messages are understandable and that the women identify with the illustrations.

\section{Gathering Information}

Fortunately Peru-Mujer had been conducting workshops throughout the country for several years and was well known in the different regions, so it wasn't difficult for them to bring together groups of illiterate women for focus group discussions (a qualitative research method in which a small number of respondents talk about a given topic under the direction of a trained moderator) on the selected themes. Although the women were initially reticent, little by little they began to express what they really thought about family planning or vaccinations. The women were pleased to coop- erate in this process, patiently explaining details when necessary. They liked the idea that someone was interested in their way of life and that a "book" was going to be done about them.

\section{Designing the Messages}

Upon completion of the focus group discussions, the information gathered was analyzed. At the same time, Peru Mujer reviewed technical and medical information on each topic to insure that the material was presented accurately. The next step was to develop a set of basic messages on each theme. In the family planning booklets, four fundamental ideas are expressed: spacing children allows them to be healthier and to have more individual attention; there are modern contraceptive methods that can be used to space children; although planning a family is a personal issue, there are other important community problems that need to be resolved; and it is important for women to organize themselves and talk over their problems as women.

Now the messages had to be translated into pictures. Finding artists who could understand the importance of reflecting the local setting in their illustrations was not easy. It took several tries before the right people were found. Once an artist had rendered an initial set of drawings, the pictures were tested. At each site, local women were asked to describe the ideas conveyed by each picture. In cases where they did not understand the message, the women were asked how they thought the idea could be better presented. For example, in the mountain region, the women said that in order to show that a man is poor, he must be shown wearing handmade woolen pants. The women were also adamant that the tri-colored bands that adorn their skirts be rendered as being a particular length and fullness and that their local hats sat on their heads at just the right angle. Only when at least 80 percent of the illiterate women who saw each picture could interpret its message correctly was an illustration considered acceptable.

In putting the messages together, it was decided that in order for the pictures to serve as a "bridge" between the women's world and presentation of "new" medical information, it would be less threatening if the messages were 


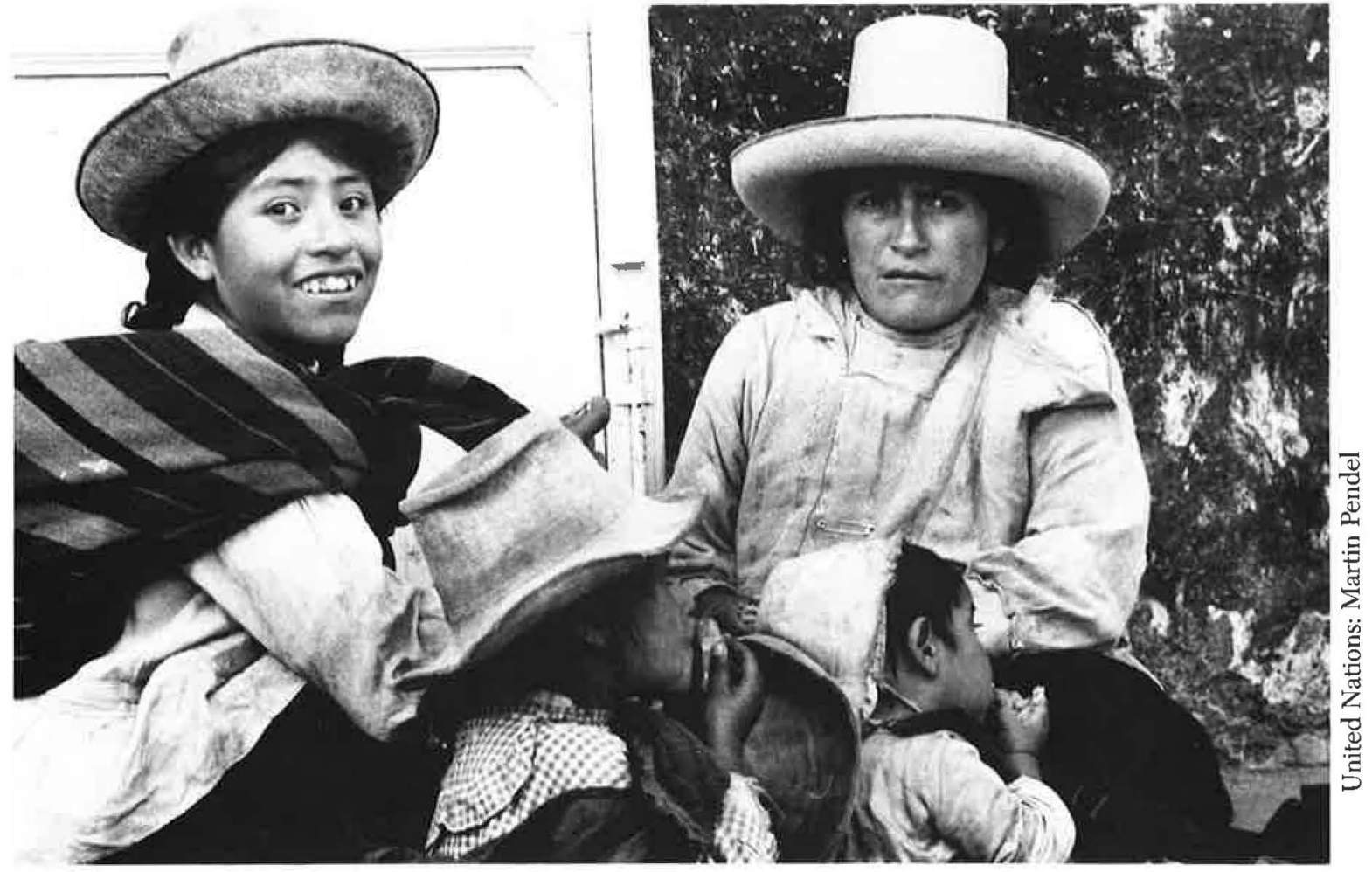

arranged so that they told a story common to everyday life. For example, the family planning booklet for the coastal area is called "The Quispes Plan Their Family." Quispe is a common name among migrants living in the marginal areas around Lima and the story line is a familiar one. The husband has no work and the child is sick. The mother cares for the child while the husband seeks financial assistance from neighbors who are unable to help as they are in the same economic situation. A neighbor recommends that the mother take the child to the health post. There the child receives care and the doctor talks to the mother about contraception as a way to provide better care to the couple's children. The wife returns home, talks to her husband, and both go to see the doctor. They choose a contraceptive method which they later discuss with their neighbors. The next-to-last picture shows a meeting of community residents where they are discussing common problems. The final illustration shows the woman at the Mother's Club looking at the booklet and discussing family planning.

During the focus group discussions, particularly in the jungle and mountain zones, women talked a lot about physical abuse from their husbands. This was an emotionally charged issue, especially as members of the group began to realize that it wasn't just them, that others also suffered the same abuse. For this reason, an illustration of a drunken, irresponsible husband was included. On the other hand, in a booklet on childbirth completed at a later date, the husband is portrayed as someone wanting to help at the time of delivery. The goal was not to label men as either irresponsible or supportive but to insure first that women identify with the illustration and then that they compare it with their own situation, discussing among themselves if the behavior is appropriate or not, if it ought to be changed and if there is something they can do about it.

\section{Testing the Booklets}

Once all the messages had achieved a comprehension level of 80 percent or higher, they were compiled in booklet form and 1,000 copies of each were printed. General comprehension of the messages was evaluated when they were used as material aids by health promoters/community workers conducting courses in 10 sites located within the three different 


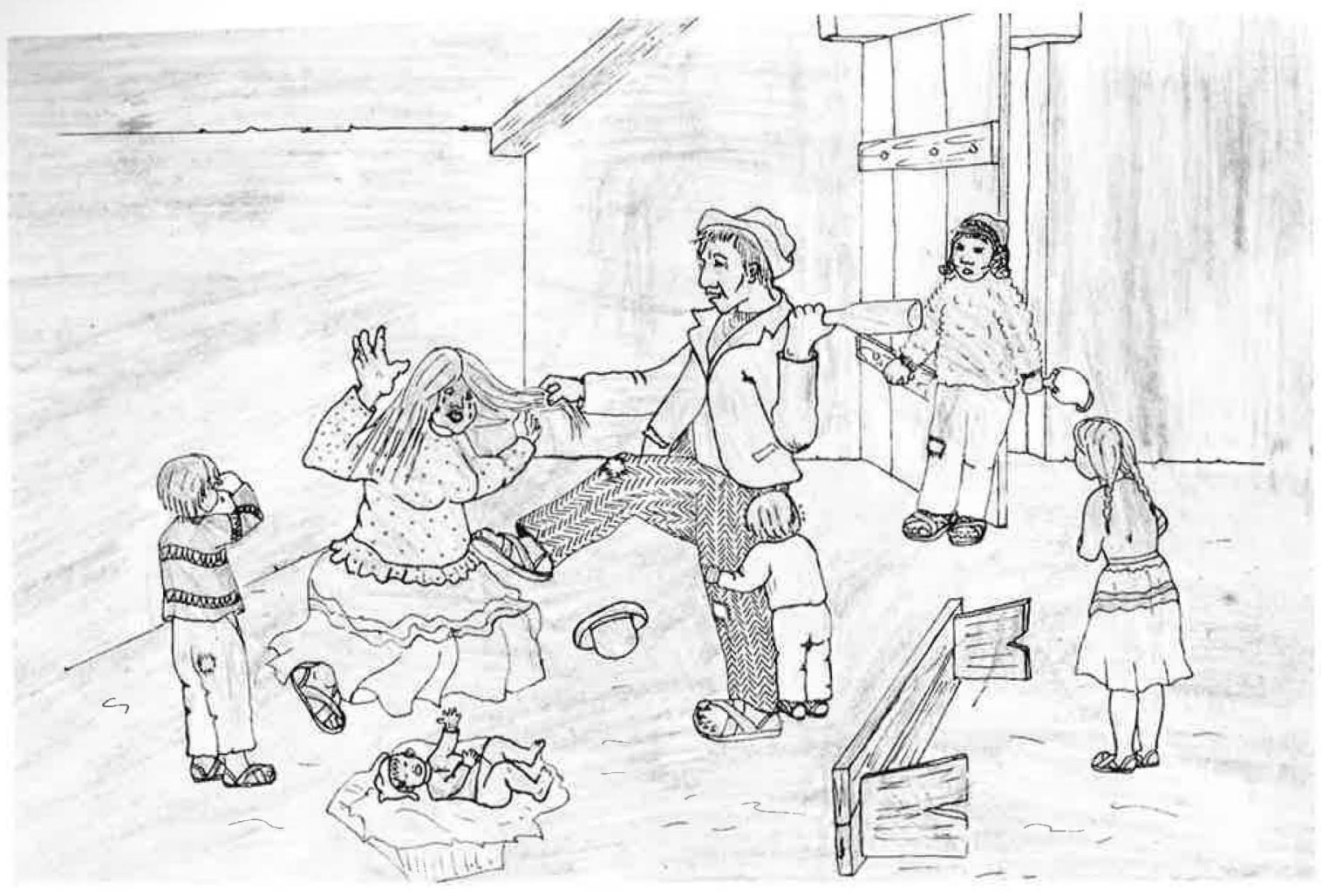

regions of the country. All of the health promoters/community workers were natives or residents of the regions where they were working and were familiar with the local population.

Ten illiterate women from the community were invited to attend each course, which was always arranged with the approval of community leaders. The women were given some support for their participation, having a choice between cash, food, wool, and so on.

A guide for the health workers was developed to accompany each booklet. The guide explains, picture-by-picture, how the booklets are to be used and how to stimulate discussion. It served as the focus for instruction during the one-week training session each promoter attended in Lima before going out to the field. Additional input on family planning was provided by staff of INPPARES (Instituto Peruano de Paternidad Responsable) and on immunization by two pediatricians specializing in community medicine.

The testing methodology was as follows: the women were shown the pictures one at a time and asked to explain what they saw. If there was no response, the promoter encouraged them to talk by using questions from the guide. If a drawing introduced new information, the women were questioned about it again later to be sure they clearly understood the concept. The following day, the women discussed what they learned the previous day. No more than five to seven illustrations were covered in one class.

\section{Coloring the Booklets}

Each woman was given a set of colored pencils at the beginning of the course along with her booklet and, at the end of each day's session, the promoter asked the women to color the pictures covered that day. The coloring book approach had been used by Peru-Mujer before as part of its legal projects and was found to hit a responsive chord.

For many poor women, particularly in the rural areas, this was the first time they ever had their own notebook and pencils, much less colored pencils! When the women took the booklets home and colored the drawings, they were often helped by their children and, at times, their husbands. In this way the themes of family planning and immunization entered the home in a natural manner to be discussed by all members of the family. Some women requested extra 
booklets to share with their neighbors and friends and, in several cases, neighbors heard about the "painting courses" and wanted to attend. In all cases the booklets were treated with great care; special bags were made for them or they were kept in plastic so they wouldn't get dirty. At each meeting the women would show the group the coloring they did at home.

While asking grown women to color pictures may sound naive, Peru-Mujer had learned previously that for poor women whose lives since infancy have been almost nothing but hard work, the inclusion of entertaining elements in a training course is very important. Being given a booklet and a set of pencils made these women, who had not gone to school or who had learned to read but forgotten, feel that they had been shown real consideration. In addition, on the last page of the booklet a diploma was printed on which the name of the participant was inscribed upon completion of the course. The women appreciated this gesture as it gave an added sense of accomplishment and it also was valued by husbands and families. Diplomas were often hung on the walls, sometimes along with the booklets.

\section{Evaluation}

Between two and four months after the conclusion of the courses, promoters held additional sessions with the participants in seven of the ten original sites, using focus group discussions and interviews to verify if women remembered what they had learned. Also, the local health post was contacted to see whether demand for family planning or immunization had increased.

In terms of family planning, participants at all sites retained an interest in the subject and requested more courses. All of them were able to identify problems associated with closely spaced births. At three sites women could identify modern contraceptives well; at the remaining four sites, fairly accurately. Use of family planning had increased $80-100$ percent in three sites, 50-80 percent in another three and less than 50 percent in one location. At six of the sites large numbers of women had enrolled in literacy courses following the training sessions. Family planning facilities at two sites reported a "considerable" increase in the use of family planning services; four sites reported "somewhat significant" increases and one site a negli-

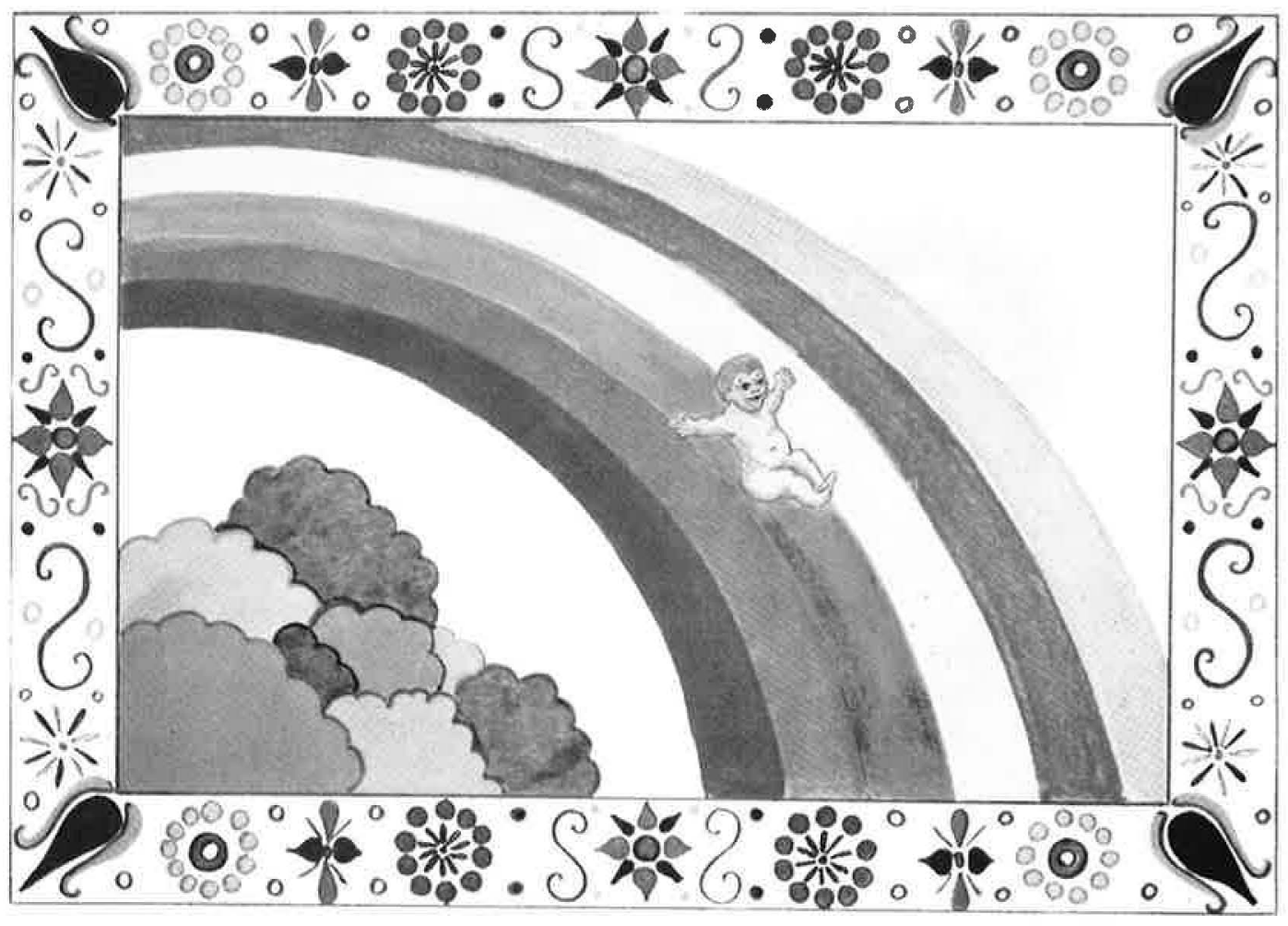


gible increase. Similar results were reported for immunization services.

In sum, the courses and booklets created motivation to make use of services, not to a dramatic degree, but sufficient to prove their utility and justify the cost. Moreover, other positive results included the increased demand for literacy courses, and in some cases the community organized other activities, such as a "medical day" where reproductive health services were provided.

\section{Importance of Involving Women in the Development of Health Materials}

For most of the participants, the courses were an important event in their lives. The women would put on their best clothes to come to class, even when they had to walk as far as 14 $\mathrm{km}$. to reach the course site. Still they were highly motivated and came every day because, working as a group, they were able to share information with others like themselves.

The participants immediately identified with the drawings-"people like us" they said. This recognition as being "ours" was very important in stimulating a dialogue among the women and also in their acceptance of the booklets. The coloring experience made the process even more personal: "(By) painting, we can add color to life."

Because the women view the booklets as their own, they not only keep them amd put them up on their walls, but also go over them again and again-commenting on the drawings they colored and sharing them with family members and friends. Involving local women in the process from the beginning means that they find the content both relevant and understandable. And because these messages and illustrations were developed and tested in each region and show respect for local traditions and the knowledge women already possess, the audience can identify easily with the pictures and are more open to accepting the new concepts incorporated in the stories.

\section{The Future}

To date, booklets have been distributed throughout Peru in collaboration with the Division of Community Participation of the Ministry of Health and the Literacy Division of the Min-

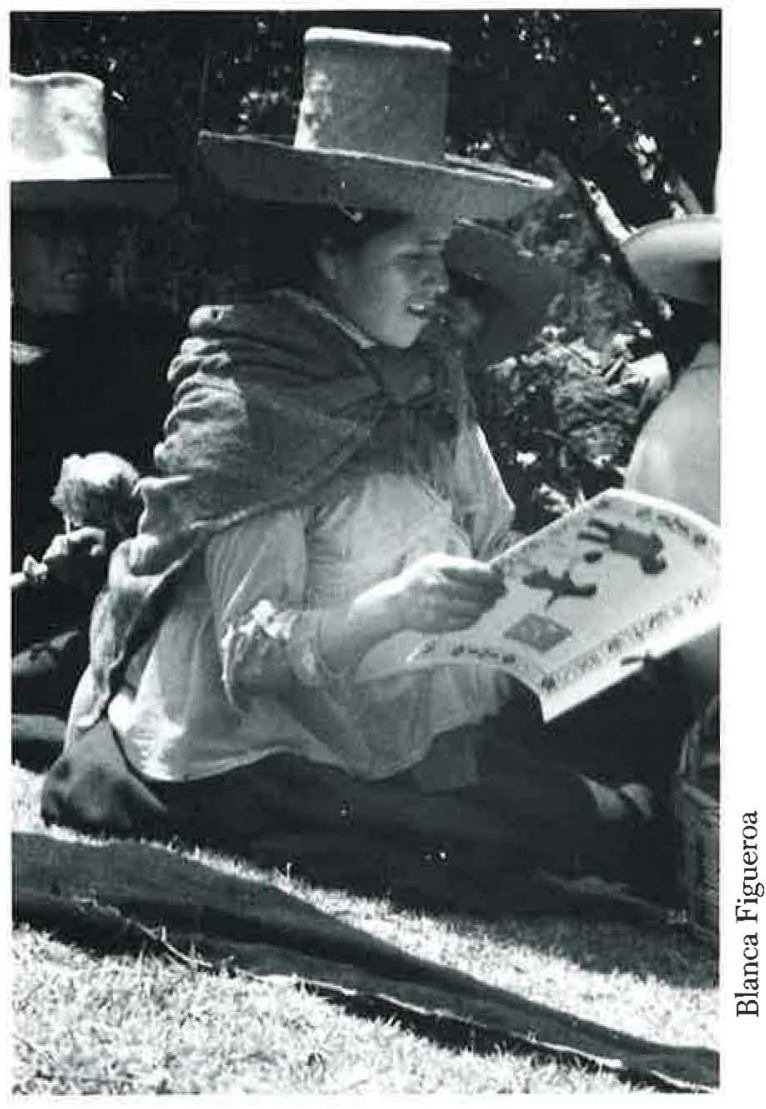

istry of Education. Following publication of the first series of booklets, Peru-Mujer produced another 19 pamphlets on subjects such as adolescent health, women and violence, sexual abuse, community organization and health.

An internal reorganization at Peru-Mujer resulted in staff changes and a shift in emphasis for the organization. This type of work now has been transferred to Asociación Gupo de Trabajo Redes. Those who were more involved in this health education project have carried their skills and experience over to new projects and are continuing to develop health and family planning educational materials. They are also interested in pursuing new activities such as creating songs and games for use in adolescent programs, developing soap operas to change attitudes towards family planning, and identifying appropriate ways to promote the use of condoms.

The work in health education has transcended institutional boundaries. This is due not only to the impact of the dissemination of materials to marginal populations, but also to the creation of a cadre of students and community workers who have mastered and apply the participative methodology. 


\section{Taboo Talk: Reproductive Health Videos by Pacific Island Women}

\section{Background}

Until the mid-1980s, little was known about women's health priorities in the South Pacific, and few women's projects had been funded. The minimal reproductive health information material available was not specifically designed for the region, and women had little voice in developing educational materials. In 1984-85 two Australian women undertook a study of reproductive health in the South Pacific for the Family Planning Federation of Australia. The researchers tapped into the extensive network of women's groups that flourish throughout the villages and towns of the region, listening to and recording what South Pacific women had to say about their reproductive health wants and needs.

The Pacific women had much to say, but overwhelmingly they spoke of the need to gain access to information, particularly about contraception, pregnancy and sexually transmitted diseases (STDs). They talked about problems of discussing such issues with families and communities, and particularly with men. They also spoke about the problem of men not taking responsibility for contraception or controlling the spread of STDs.

When asked what medium would be the most appropriate way to present information on these topics, the women strongly favored video. It was felt that video could present the information in a story-telling style that was in keeping with Pacific tradition and that this medium could offer an acceptable way of presenting topics that would otherwise be subject to cultural, particularly sexual, taboos that often limit the effectiveness of health education workers. Although distribution of video equipment within the region is uneven, the technology is generally available and accessible.

In 1987 the Family Planning Federation of Australia obtained funding from the Australian International Development Assistance Bureau to produce reproductive health videos that would meet the needs identified.

\section{The Project}

Before undertaking the project, the basic research study was updated to see if Pacific women still had the same priorities they had expressed two to three years earlier. This brought to light a new concern: AIDS. It was therefore decided that three videos would be produced on the following subjects: 1) AIDS and the South Pacific; 2) Better Safe, dealing with sexually transmitted diseases; and 3) Taboo Talk, a discussion of women's attitudes towards menstruation, sex education and family plamning.

The three videos differ not only in subject matter but in style of presentation as well. Extensive planning workshops with Pacific women resulted in the selection of very different modes of presentation for each of the three subjects.

AIDS in the South Pacific uses two wellrespected figures, a female academic and a male physician, to present controversial material with the voice of authority. Explicit AIDS information was considered too sensitive to present in any other way than a sermon-like delivery that would give some credibility to the messages and help overcome the general reticence to discuss sexual subjects publicly.

Better Safe is a drama about sexually transmitted diseases, condom use and male sexual responsibility. The video uses actors to create a story about a young man who moves between his city and village girlfriends. The video tries to expose some of the attitudinal differences between men and women and rural and urban areas, as well as to trigger discussion about realistic STD prevention options.

Taboo Talk documents a wide range of Pacific women, young/old, urban/rural, educated/uneducated, voicing their experiences, hopes and concerns. The tape incorporates scenes of village life, including the singing of traditional songs. The aim is to encourage open discussion about reproductive health issues and to generate an appreciation of the similarities of experience among women throughout the region. 


\section{Producing the Videos}

The Pacific island of Fiji was chosen as the site for filming the videos because it is home to a wide cross-section of Pacific people as well as a number of media production facilities. In addition, the budget could not be stretched to include filming in more than one country.

Women administered and carried out the entire project. Although the videos and their use were the end-product of the project, the process of producing them was of equal importance. Pacific women were included in all phases from initial research to production and distribution. The original plan was to use a Pacific women's video film crew, but when it became apparent that none existed, the project was redesigned. A women's film crew was brought from Australia with the understanding that a component of the project would be to train a local women's film crew as part of the process. The selection of film trainees was based on their past involvement in media work, an interest and background in women's activities and the potential for future use of their skills in other projects.

Scripts were developed but were intended to be used only as guides that would be modi- fied during workshops with Pacific women. The workshops continued until appropriate language, beliefs, values, style of presentation, length, religious involvement and priorities were determined. For example, due to the important part that religion plays in the life of Pacific people, women wanted the two principal churches represented in the AIDS video to give credibility and authority to the messages. And because Pacific men don't tend to involve themselves in "women's business," women wanted their STD video to focus on the need for men to become active participants.

The project was designed to take into account the cultural and religious sensitivities of those involved and, because it was a video project for women and by women, it was carried out according to women's priorities. Although women were initially reticent about speaking on camera, they still had a strong desire to do so. The presence of a supportive women's film crew helped them to overcome their reserve. In one instance, the filming triggered some painful memories about a woman's past and she started to cry. Instead of continuing to shoot what could have been some sensational footage, the crew stopped and began to

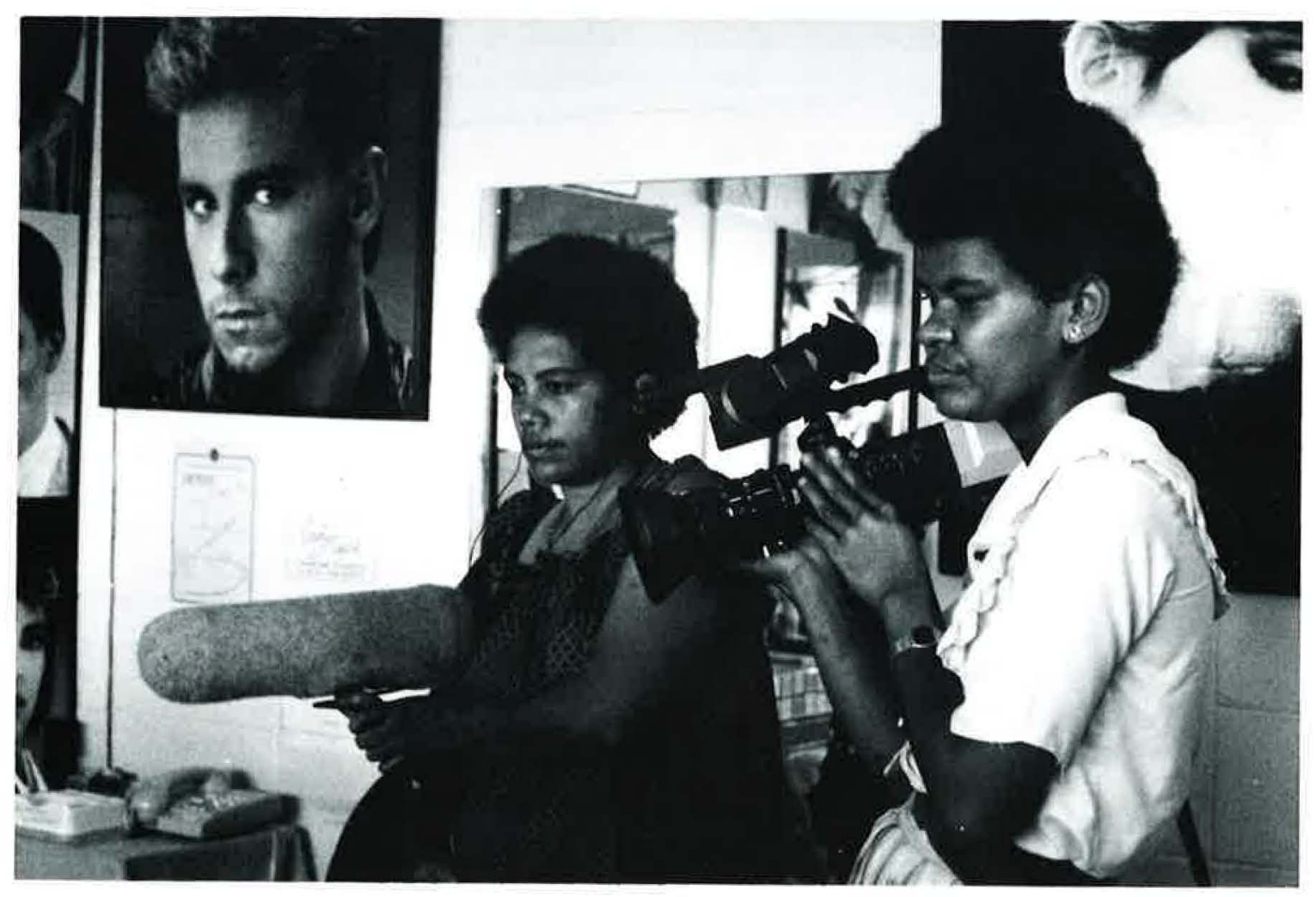


share their own reproductive experiences. This brought a realization that women's experiences transcend nationalities and that the film could highlight that universal experience in a positive way, rather than dissect Pacific women's experience for its curiosity value.

The South Pacific region is racially and culturally diverse. Although sexual taboos are taken very seriously, they vary from country to country. Thus it was difficult to decide whether an explicit scene, such as that of a condom being unrolled onto a model of an erect penis, would be acceptable to audiences throughout the region. After numerous discussions with women's groups, it was decided that the scene should be included, and no negative feedback has resulted. This underscores the importance of incorporating a thorough consultation about style and content with the audience throughout the process of materials development.

\section{Distribution and Use}

The launch of the videos was scheduled to coincide with the Fourth Regional Women's Conference held in Fiji in September 1988. Scores of women from throughout the Pacific region attended the conference. Screenings were also held at the various sites where filming had taken place, including in the villages. Media representatives were invited to these screenings, resulting in newspaper articles and interviews on Radio Fiji. Advertising broadsheets were sent to contacts throughout the region. All the feedback from these early contacts was favorable.

The videos are now being distributed through the independent, nongovernmental family planning associations in Papua New Guinea, Solomon Islands, Tonga, Fiji and Western Samoa and are being used in 16 Pacific countries. They are being screened by departments of health and education, women's and youth groups, nongovernmental organizations involved in health education and churches. AIDS and the South Pacific and Better Safe have been shown on national television in Papua New Guinea and Palau and have become "recommended videos" for regional AIDS education curricula in high schools. A particularly innovative means of distribution was pur- sued in Fiji, where the leading commercial distributor of rental home videos included the AIDS film as a "short subject" on popular rented films. The Australian government has also bought copies for distribution to health workers in areas of Australia with large Pacific Island communities.

In 1989 an evaluation of the project was carried out to analyze both the process of video production and the impact of the videos in terms of distribution, acceptability, appropriateness and effectiveness. The videos' ability to encourage discussion about hitherto publicly avoided subjects was widely applauded. Both educators and audiences highlight two areas in which the videos excel: their Pacific flavor and their ability to trigger discussion.

Although the project was designed to produce educational resources for women, men too showed an enormous interest in the reproductive health subjects. Video screenings frequently prompted requests by both men and women for more videos on sexuality and contraceptive methods targeted at men. When Taboo Talk was first produced, the women were reticent about Pacific Island men seeing the film, fearing males would have a negative response to women expressing their thoughts and feelings in this way. As a consequence, initial screenings of this particular film were restricted to female audiences and non-Pacific Islander males. However, it was not possible to control viewing audiences once distribution spread, so the evaluaation was particularly interested in learning the reactions of Pacific men to the film. They were found to be very positive. Men were fascinated by the women's ability to speak out on these subjects and wanted a chance to do the same, especially about their views on contraception and the male sexual role. Requests for a male version of Taboo Talk were widespread.

Distribution remains a continuing problem in the region. Although the videos are being widely used, their availability is uneven, with usage dwindling the farther one moves away from urban areas. Future distribution would be greatly enhanced by a face-to-face promotion tour throughout the region and by increasing the number of distributors to include regional organizations. Use could be further enhanced by providing accompanying print materials that give specific details about target 


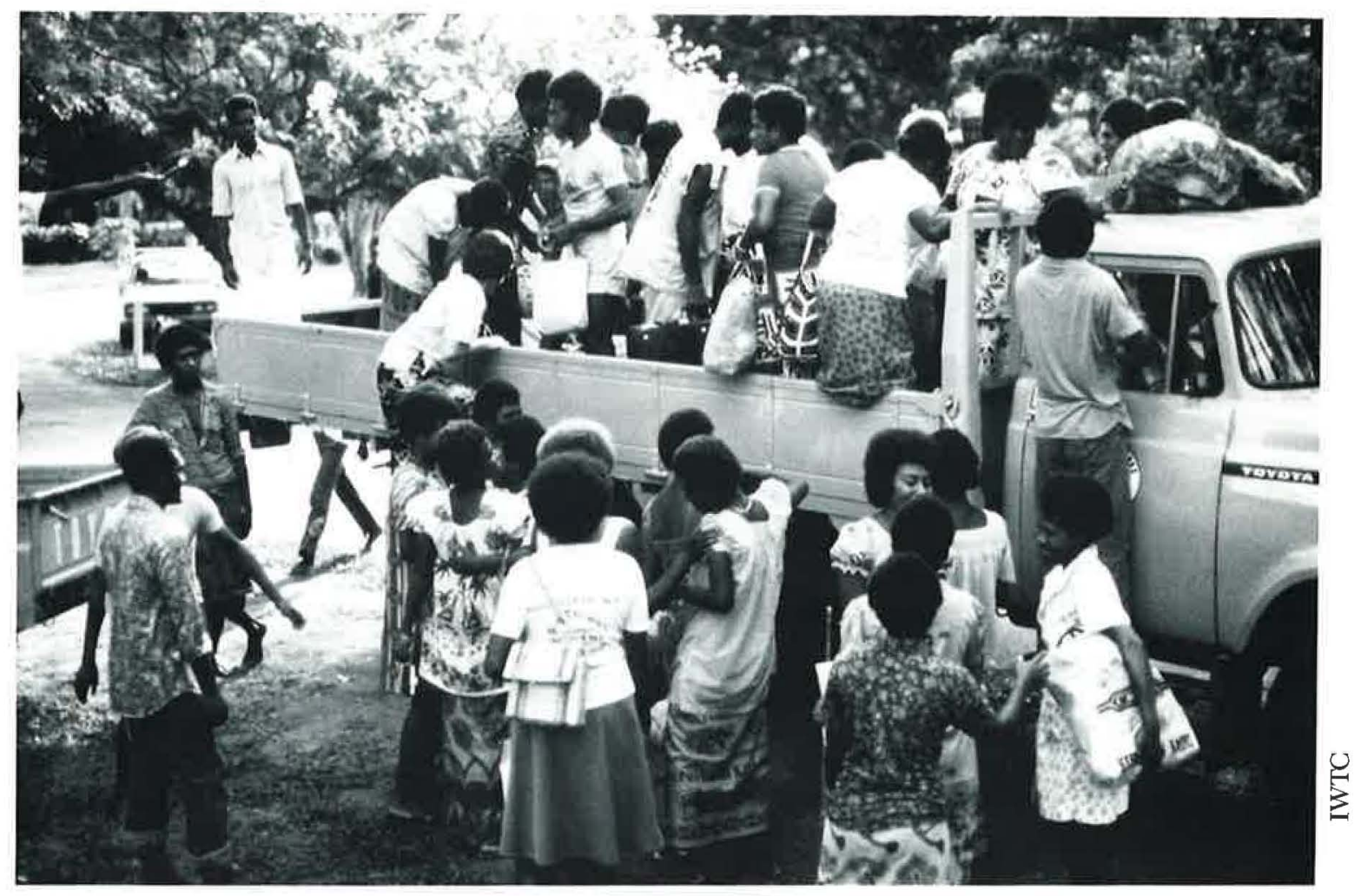

audience, aims and objectives of each tape and suggestions for use.

Language is another problem. English is the only common language in the Pacific and, therefore, if only one version can be produced for the region, it must be in English. However, versions in the local vernacular would be more effective for reaching people in rural areas and for older people. Fortunately, a follow-up project has now been funded that will translate the video into five Pacific languages. Development of these translations will also be done through community women's groups.

Recognition of the film training compo- nent in the project could have been reinforced by presenting the trainees with a certificate on completion of their apprenticeship, giving increased status to their efforts. Encouragingly, despite the lack of formal recognition, members of the trainee film crew have used the experience both to obtain better jobs and to broaden the scope of their present work. All are confident they can produce their own videos in the future.

It is a testament to the skills of all the women involved that governments around the Pacific are now using a nongovernment resource produced entirely by women. 


\section{Afterword}

The differences among the three projects described here demonstrate that there is no standard pattern for success in developing appropriate materials and effective approaches to reach women with health information. The case studies can, however, stimulate us to think about some basic principles that will be helpful to those involved in similar efforts. Readers who want to learn more about the individual projects can refer to the Appendix, where contact information and other resources are listed.

\section{No Short Cuts}

Development of quality information materials takes time. Each chapter of the Cairo Women's Health Collective's book was revised four times, even before pretesting; both the content and the approach were discussed at length until consensus was reached. In Peru, painstaking attention to details, such as the dress styles depicted in the illustrations, meant that each picture went through several-sometimes many-versions in order to increase the effectiveness of the message. Consultation among the culturally heterogeneous women of the Pacific was necessary to establish the acceptability of potentially sensitive subjects; production could have been faster without it, but judging from the evaluation, the videos may not have had the same impact.

\section{Know the Audience}

One of the most time-consuming, yet rewarding, aspects of all three projects was the extensive interaction with the intended audience. This was achieved in different ways-seminars, meetings with women's groups, focus group discussions-and at different stages of the process, but in each case these consultations provided information indispensable to the final product. Such a process is not always applied in developing health information materials although, when women are the audience, it is particularly crucial because they are seldom asked about their needs and opinions.

Assumptions about what women want, or can do, can be misleading. The producers of the video Taboo Talk could have accepted the conventional wisdom that Pacific women would not discuss sexuality and simply produced a didactic film. Instead, they invested time in talking with women's groups throughout the region. This gave them a completely different picture of the situation. The result is a sensitive, moving production that enables other Pacific women to learn from their sisters' discussion of their reproductive health experiences and feelings.

\section{...and Its Variety}

Although women's problems and health needs have much in common, it is a mistake to treat women as a homogeneous audience. In Peru, the project had to adapt basic family planning information materials for women in each of the three main cultural regions of the country, and the Cairo health book had to be sensitive to Christian as well as Muslim beliefs. The choice of English as the language for the Pacific videos has enabled them to be used throughout the region but, in some cases, it has limited the audience, with older women and those in rural areas less likely to be reached.

\section{Pictures, Books, Film?}

The choice of which media to use is a difficult one, and decisions once again must be based upon knowledge of your audience. Pictorial material and accompanying courses designed for illiterate people are critical in many countries and will remain so for older women even in countries where formal schooling is becoming more accessible to the young. However, the demand for written materials needs to be monitored as the education profile of women changes, and consideration needs to be given to emerging forms of the popular press such as women's magazines. Videos also can be appropriate where a large proportion of the intended audience has access to the technology and where maintenance is not a problem. As the author of the Pacific project report discusses, the impact of the videos probably could have been greater if they had been accompanied by print material explaining their objectives and use, and if they had been distributed through a promotional tour along with face-toface communication. 


\section{Some Technical Lessons}

Many technical problems that can arise in producing health information materials-such as comprehension of visual messages-may apply equally to male and female audiences. But because women are often less familiar with the "outside world," it is sometimes necessary to make a special effort to ensure that materials will not only reach but also be understood by the female population. Studies often claim that material was discussed with an undefined group of "villagers" or "the community," but unless special attempts were made to elicit women's contributions, this often means male villagers and male members of the community were consulted and does not guarantee that women's viewpoints have been represented.

Where women are the intended audience, their involvement is essential not only to ensure that messages are technically appropriate but also to validate that they are relevant to women's perceived problems and their view of the world. In Peru, incorporating women's advice into drawings and stories meant that the pictures were more than just recognizable-women identified with them.

\section{Importance of the Process Itself}

The fact that women so rarely have a voice in decision making makes the total development process described in these case studies a pathbreaking experience. Its value extends both to the women who are the intended users as well as to those involved in production. Participating in courses and obtaining a diploma, being members of focus group discussions, responding to pretest material, talking about personal experiences in a film-all can reinforce women's networks and raise individual self-esteem. For the producers of the material, the same functions are served through the activities involved in implementing these projects-forming a women's collective, training in participatory methodologies, taking part in discussions and interacting with service providers. In the Pacific, an all-women film crew was trained, opening up new employment opportunities for them after the project. Whether the rewards were material, professional, social, or personal, those involved in carrying out each project felt that much more had been gained than just the production of information materials.

\section{Building on the Investment}

All the projects discussed here are leading to expanded or new activities that will make use of the experiences and results gained, thus broadening the impact of materials that have been shown to be effective. Similarly, the experience gained by the participants can be drawn upon in future activities to influence even larger groups of people.

In Cairo, where so much time and effort went into preparing material for the book, suggestions for the future include converting individual chapters into pamphlets, as well as spreading the messages through other forms of media, including women's magazines. In Peru, too, women are considering other ways of delivering educational messages: through songs, games and soap operas. The positive male response to the women pictured in the Pacific videos may lead to a related project that will record male perspectives in reproductive health, and the existing videos are being translated into five Pacific languages.

\section{Links between Information and Services}

The involvement of service providers in the process of developing and disseminating reproductive health information for women can yield many dividends. Links with health workers can ensure that the information provided accurately depicts available services so that women's expectations will be realistic. While providing technical advice on the Cairo book, medically trained collective members and advisors not only provided advice, but also had the opportunity to engage in debate that broadened their perspectives on women's health. The Peru-Mujer materials were produced for use by health promoters/community workers, who helped to pretest the materials with women in local communities. In the Pacific AIDS video, the involvement of the medical establishment helped to lend credibility to the presentation of sensitive material and links with Pacific family planning associations were valuable not only during production but also for distribution of the videos through their networks. 
Health information materials developed by and for women enable women to help themselves - to become more knowledgeable about available services, more confident about using them, and better able to mobilize to demand improved services. In Peru the health information courses led to increased demand for literacy training and the organization of activities such as a "medical day" where reproductive health services were provided.
More than this, the link between information and services is fundamental in a conceptual sense. The current trend toward placing more emphasis on quality of care and incorporating a "user perspective" in service delivery extends logically to the involvement of women in the development of information materials. Materials that are based on respect for the woman clienther needs, her beliefs and her contributionswill be those that women understand and use.

\section{Résumé en français}

Linformation est la clé pour comprendre et faire face au changement. C'est la condition pour une meilleure prise de conscience de soi-même et pour donner aux individus les moyens d'exercer plus de contrôle sur leur propre vie. Probablement nulle part ailleurs n'est la question de l'accès à l'information aussi cruciale que dans le domaine de la santé des femmes-particulièrement en ce qui concerne la santé de la reproduction des femmes. Dans la seconde moitié de ce siècle, les professionnels de la médecine ont eu tendance non seulement à se sentir propriétaire du savoir en matière de santé de la reproduction mais encore à refuser de le partager avec les dispensateurs traditionnels de soins, c'est-àdire, les sages-femmes et les femmes elles-mêmes.

En conséquence, les groupements féminins oeuvrant pour la santé des femmes sont devenus particulièrement actifs et ont commencé à se faire entendre au cours de ces dernières années. Gräce, surtout, aux efforts déployés par les femmes travaillant à la base ou en milieu académique ou hospitalier, les professionnels de la planification familiale ont fini par réaliser que pour favoriser l'adoption et l'utilisation continue d'une méthode contraceptive, on ne pouvait se contenter de motiver les clients potentiels; il fallait, en fait, leur donner des informations complètes et pertinentes sur les méthodes contraceptives et s'assurer, par ailleurs, que les clients pouvaient se les procurer facilement. On s'est également rendu compte que, pour être utile, l'information devait être intelligible et attrayante pour le public visé et être présentée sous une forme qui reflète la réalité.

\section{Matériels d'information par et pour les femmes: Quelques défis à relever}

Le développement de matériels d'information sur la santé par et pour les femmes se heurte non seulement à des problèmes techniques courants mais également à des obstacles plus fondamentals. Les femmes, plus particulièrement les femmes pauvres, risquent souvent d'être marginalisées par la société. Elles sont également plus nombreuses que les hommes à être analphabètes ou à avoir perdu la capacité de lire par manque de pratique. En outre, on les intimident ou les empëchent d'avoir accès à l'information moderne et elles sont tenues à l'écart de toutes les prises de décisions.

Le processus de développement de matériels sur la santé par et pour les femmes peut constituer un contexte sécurisant dans le cadre duquel les femmes ont la possibilité de poser des questions, de parler de leur vécu et d'échanger des informations sur des sujets qu'ils seraient impossible d'aborder dans un environnement mixte. Un tel processus aide également les femmes à se valoriser puisqu'elles s'apperçoivent qu'elles ne sont pas seules, que d'autres femmes partagent les mêmes problèmes et préoccupations et qu'elles peuvent apprendre de leurs expériences mutuelles.

\section{Les études de cas}

Préoccupées par le manque de connaissances des femmes dans leur région sur leurs besoins en matière de santé, 25 femmes du Caire, de milieu social, de groupes d’âge et de catégories professionnelles très différents, ont décidé de former le "Collectif du Caire pour l'information des femmes sur la santé". S'inspirant de "Notre corps, nous-mêmes" le fameux livre publié par le "Collectif de Boston pour l'information des femmes sur la santé", leur intention était de publier un ouvrage sur la santé qui serait écrit exclusivement par des femmes et du point de vue des femmes égyptiennes. 
Le fruit de leurs efforts s'intitule "Vie et santé des femmes en Egypte". Il s'agit d'un guide sur la santé destiné aux femmes de la région et reflète des questions culturelles et des circonstances contemporaines particulières à l'Egypte. Publié en 1991, ce guide fut développé à travers un long processus de négociations et de compromis. Il ne s'agit ni d'une traduction ni d'une adaptation mais d'un ouvrage inédit et est entièrement rédigé du point de vue des femmes dans un style amical et à la portée de tous. C'est également un livre objectif puisqu'il n'essaye d'imposer aucune vue particulière à ses lectrices mais au contraire de les amener à tirer leurs propres conclusions. Le livre se vend même mieux que prévu et une deuxième impression aura lieu début 1992.

Peru-Mujer, ONG péruvienne, en collaboration avec PATH (Programme de Technologie Appropriée en Santé) a entrepris un projet pour développer des brochures illustrées sur la planification familiale et la vaccination à l'intention des femmes illettrées et peu instruites. Les concepteurs ont adopté une approche centrée sur les femmes en faisant une utilisation positive des connaissances existants chez les femmes et de leur vécu et ont crée un climat de confiance propice à combattre les idées fausses et à faire cesser les pratiques néfastes.

Des brochures différentes ont été développées pour chacune des trois régions du Pérou et, dans chacun des cas, les concepteurs ont pris soin de les tester avec les femmes. Les brochures ont ensuite été utilisées dans des cours de formation. Lun des aspects uniques de ce projet était que les femmes (et souvent leurs enfants et même leurs maris!) coloriaient eux-mêmes les illustrations avec des crayons de couleurs qu'on leur avait donnés. Pour bien des femmes, c'était la première fois qu'elles tenaient un crayon de couleur entre leurs doigts; cette activité non seulement développait l'intérêt des femmes mais rendaient les brochures plus valables non seulement à leurs propres yeux mais aux yeux de la collectivité toute entière.
Une évaluation du projet a révélé que l'information avait bien été mémorisée et que le taux de fréquentation des services de santé et de planification familiale avait augmenté. Parmi les autres résultats positifs, il convient de noter les nombreuses demandes de participation à des cours pour apprendre à lire et à écrire et, dans certains cas, d'organisation d'activités au niveau de la collectivité.

Dans le Pacifique Sud, l’on a demandé aux femmes quels étaient leurs besoins en matière de santé de la reproduction et quels types de matériels pouvaient, selon elles, le mieux communiquer les renseignements qu'elles souhaitaient recevoir. Le résultat fut un projet vidéo entièrement réalisé par des femmes et du point de vue des femmes avec la production des trois vidéos suivantes: 1) Le Sida et le Pacifique Sud; 2) Mieux vaut être prudent, consacré aux maladies sexuellement transmissibles; et 3) Conversations tabous, une discussion sur l'attitude des femmes envers la menstruation, l'éducation à la vie familiale et la planification familiale.

Du début à la fin, le projet a été entièrement réalisé par des femmes. Bien que les vidéos et leur utilisation étaient le produit final, le processus de production était d'une importance toute aussi capitale. Les fermmes de la région étaient inclues à toutes les phases du projet depuis la recherche initiale jusqu'à la production et la distribution. Etant donné qu'aucune équipe de tournage féminine n'était disponible sur place, l'on a fait venir une équipe australienne sous condition qu'elle formerait une équipe locale dans la production de vidéos.

A présent, les vidéos sont utilisées dans 16 pays du Pacifique Sud. Une évaluation réalisée en 1989 a révélé que les vidéos sont capables de susciter des discussions sur des sujets dont auparavant il ne fallait pas parler ouvertement. Selon les éducateurs et les spectateurs, les deux domaines dans lesquels les vidéos excellent sont le fait qu'elles rendent bien l'atmosphère du Pacifique et leur capacité à stimuler la discussion.

\section{Resumen en Español}

La información es la clave mediante la cual comprendemos y nos adaptamos al cambio. También es la base sobre la cual ampliamos nuestro conocimiento propio y ejercemos un mayor control sobre nuestras vidas. El problema del acceso a la información es especialmente crítico cuando se trata de la salud de la mujer, y en particular de su salud reproductiva. Tradicionalmente, las parteras y las mujeres mismas se han encargado de las prácticas y los servicios relativos a la atención en salud reproductiva. Pero durante la segunda mitad de este siglo el sector médico profesional ha expropiado estas funciones, limitando el acceso de las mujeres a la información sobre el cuidado de sus propios cuerpos.
En respuesta a este fenómeno, los grupos de salud de la mujer han intensificado sus actividades y reivindicaciones en años recientes. Gracias a los esfuerzos de mujeres que han trabajado en los niveles locales, institucionales y académicos, los profesionales de planificación familiar han empezado a reconocer que sus responsabilidades requieren algo más que la simple motivación de posibles clientes. Es necesario además que la cliente reciba información completa y exacta sobre los métodos anticonceptivos, y que existan servicios lo suficientemente accesibles como para facilitar no sólo la adopción, sino el uso continuado de la anticoncepción. También se está empezando a reconocer que si la infor- 
mación exacta se presenta de un modo desagradable o incomprensible, o si no refleja la realidad en cuanto a los servicios disponibles, da lo mismo no ofrecer información alguna.

\section{Materiales informativos hechos por y para la mujer: algunos desafíos especiales}

Además de presentar problemas técnicos comunes, el desarrollo de materiales de información sobre salud por y para mujeres implica una serie de desafíos básicos. Las mujeres, y especialmente las mujeres pobres, tienden a estar marginadas tanto en su condición física como en su posición dentro de la sociedad. Comparadas con los hombres, también tienen una mayor probabilidad de ser analfabetas o de haber perdido la capacidad de leer por falta de práctica. Estos factores contribuyen a que las mujeres sean excluidas de los procesos de decisión, y hacen que se sientan intimidadas por la información moderna en las pocas ocasiones en que tienen acceso a la misma.

El proceso de desarrollo de materiales de salud por y para mujeres permite crear un ambiente seguro en el cual las mujeres pueden hacer preguntas, discutir temas y compartir información de un modo que jamás sería posible en un contexto coeducacional. El proceso también ayuda a fortalecer el sentido de dignidad de las mujeres, a medida que se dan cuenta de que no están solas y que otras mujeres comparten sus problemas y pueden aprender de sus experiencias.

\section{Las experiencias}

La Colectividad para Libros sobre Salud de la Mujer de Cairo fue formada por 25 mujeres de distintas edades, clases sociales y ocupaciones que comparten una inquietud por la salud reproductiva de la mujer. Inspiradas por el famoso libro de la Colectividad para la Salud de la Mujer de Boston, Our Bodies, Ourselves ("Nuestros cuerpos, nuestras mismas"), las mujeres de Cairo decidieron producir un libro sobre salud hecho por y para la mujer egipcia.

El resultado de sus esfuerzos se llama La vida y la salud de la mujer en Egipto, y consiste en una guía sobre salud para mujeres, escrita en árabe, que refleja la cultura y las circunstancias del Egipto actual. El libro, editado en 1991, fue desarrollado a través de un proceso de negociación y conceciones. Se lo escribió desde la perspectiva de la mujer, en un estilo informal y accesible, y empleando sólo material original, en vez de adaptar materiales existentes. Las redactoras también buscaron ser objetivas, sin imponer un punto de vista particular, con el propósito de que cada mujer llegue a sus propias conclusiones. El libro se ha vendido en cantidades muchos mayores a lo esperado, y se anticipa una segunda tirada a principios de 1992.

Trabajando en conjunto con el Programa para la Technología Apropiado en la Salud (PATH), Perú-
Mujer, una organización peruana privada, emprendió un proyecto para desarrollar materiales impresos sobre planificación familiar e inmunización para mujeres analfabetas o de alfabetismo limitado. El proyecto estableció una perspectiva centrada en la mujer que aprovechó de los conocimientos y la experiencia que las mujeres ya poseen y creó una base de confianza sobre la cual se pueda empezar a cambiar ideas y prácticas negativas.

Se diseñaron folletos distintos para cada una de las regiones geográficas del Perú, y cada uno fue cuidadosamente probado con mujeres locales. Posteriormente los folletos se emplearon durante cursos de entrenamiento. Uno de los aspectos singulares del proyecto fue que las mujeres (y a veces sus hijos y maridos) se encargaron de colorear las ilustraciones de los folletos, usando lápices provistos por el proyecto. Esta fue la primera vez que muchas de las mujeres habían poseído un lápiz de color, por lo cual la actividad no sólo estimuló interés en el proyecto, sino que aumentó el valor de los materiales para ellas y para la comunidad en general.

Una evaluación del proyecto reveló buenos niveles de retención de la información y un aumento en el uso de anticonceptivos y servicios de salud. Entre otros resultados positivos se destacaron una mayor demanda por cursos de alfabetización y, en algunos casos, la organización de actividades por la comunidad.

En el Pacífico Sur se llevó a cabo un levantamiento para determinar cuáles eran las necesidades de salud reproductiva de las mujeres locales y qué tipos de materiales serían los más adecuados para proveerles la información que desean. El resultado fue un proyecto que produjo tres videos hechos por y para mujeres: 1) SIDA y el Pacífico Sur; 2) Better Safe ("Es mejor estar segura"), sobre la prevención de las enfermedades de transmisión sexual; y 3) Taboo Talk ("Temas tabú"), una discusión sobre las actitudes de la mujer hacia la menstruación, la educación sexual y la planificación familiar.

El proyecto fue administrado y ejecutado exclusivamente por mujeres. Aunque la difusión de los videos fue el producto final, el proceso de producción en sí tuvo la misma importancia. Todas las etapas del proyecto, desde la investigación inicial hasta la producción y distribución, incluyeron a mujeres locales. Cuando se descubrió que no se disponía de un equipo femenino de filmación local, se contrató a uno de Australia con la condición de que sus integrantes le enseñaran técnicas de producción de video a las mujeres locales como parte del proyecto.

Actualmente los videos se están utilizando en 16 países del Pacífico Sur. Una evaluación realizada en 1989 subrayó la capacidad de los videos de motivar discusiones sobre temas que previamente no se hubieran podido abarcar en público. Tanto los educadores como el público señalaron dos aspectos sobresalientes de los videos: su singular sabor Pacífico y su capacidad para provocar la discusión. 


\section{Appendix}

Listed below is contact information for those involved in developing the materials highlighted in this edition of Quality/Calidad/Qualité, along with several other organizations engaged in the production and/or dissemination of health materials developed by and for women. Also listed are several publications of possible interest.

\section{Resources}

Cairo Women's Health Book Collective

c/o Delta Associates

12 Muamal el Sukkar

Garden City

Cairo, Egypt

For information about the Collective or obtaining the book.

Blanca Figueroa

Grupo de Trabajo Redes

Apartado Postal 1578

Lima 18, Perú

For further information on the development of women's health materials in Peru.

Family Planning Federation of Australia

39 Geils Court

Deakin ACT, Australia

For further information about the Pacific video project or about obtaining copies of the videos.

Boston Women's Health Book Collective

P.O. Box 192

West Somerville, MA 02144, U.S.A.

Authors of Our Bodies, Ourselves. Work with groups in other countries to produce health materials.

ISIS International

85-A East Maya St.

Philamlife Homes

Quezon City

The Philippines

and

ISIS International

Casilla 2067

Correo Central

Santiago, Chile

Women's information \& communication service. Publications, technical assistance $\&$ training in communication skills and management.
National Black Women's Health Project

1237 Gordon St., S.W.

Atlanta, GA 30310 U.S.A.

Originally U.S. based, they now have an international program. Extensive experience working with disenfranchised women and helping them take responsibility for their health care.

\section{Publications}

(Please contact publishers directly regarding availability, cost and shipping charges, which may be applicable.)

Developing Health and Family Planning Print Materials for Low-Literate Audiences: A Guide, by Zimmerman, Newton, Frumin and Wittet

Program for Appropriate Technology in Health (PATH)

1990 "M" Street, N.W.

Washington, D.C. 20036 U.S.A.

Telephone: (202) 822-0033

In Her Own Image: Films and Videos Empowering Women for the Future

Media Network

39 W. 14th. Street

Suite 403

New York, NY 10011 USA

Telephone: (212) 929-2663

Asian and Pacific Women's Resource and Action Series: Health

Asia \& Pacific Development Centre

P.O. Box 12224

Kuala Lumpur 50770, Malaysia

Telephone: 603-254-8088 


\section{About the Authors}

Valerie Hull is a demographer with extensive experience working in developing countries. She is currently the Director of the Women, Health and Population Section of the Australian Development Assistance Bureau. At the time the Cairo Health Book was being developed, Barbara Ibrahim was the Urban Program Officer in the Ford Foundation's Cairo office; she is currently the Population Council's Senior Representative for West Asia and North Africa. Nadia Farah is Director of the Cairo Center for Development Studies and Coordinator of the Cairo Women's Health Book Collective. Blanca Figueroa was one of the founders of Peru-Mujer and continues her work on development of health materials for women as the director of the Grupo de Trabajo Redes in Lima, Peru. Margaret Winn was involved in the planning, implementation and evaluation of the South Pacific Women's Video Project; she is currently a consultant on reproductive health in the South Pacific and an AIDS educator based in Australia.

\section{Quality/Calidad/Qualité Advisory Committee}

\author{
Ian Askew \\ George Brown \\ Judith Bruce \\ Ethel Churchill \\ Adrienne Germain \\ Margaret Hempel \\ Ann Leonard \\ Margaret McEvoy \\ John Paxman
}

\author{
Debbie Rogow \\ Jill Sheffield \\ Lindsay Stewart \\ Kerstin Trone \\ Nahid Toubia \\ Gilberte Vansintejan \\ Cynthia Steele Verme \\ Beverly Winikoff \\ Margot Zimmerman
}

\author{
Design: Ann Leonard \\ Cover Photo: Institute of Cultural Affairs, \\ Bayad al Arab, Egypt \\ Typography: Village Type \& Graphics \\ Printing: Graphic Impressions
}

We invite your comments and your ideas for projects which might be included in future editions of Quality/Calidad/Qualité. If you would like to be included on our mailing list, please write to Ann Leonard, Quality/Calidad/Qualité, The Population Council, One Dag Hammarskjold Plaza, New York, N.Y. 10017, U.S.A. 